\title{
Besikeičiantis Baltijos jūros regiono saugumo režimas"
}

\begin{abstract}
Nors Baltijos jūros regionas atrodo lyg ideali vieta, kur būtų galima suformuoti klasikinị pilnavertị regioninị saugumo režimą, ši prielaida iš esmès pasirodo esanti klaidinga. Deja, ị regioninị formatą niekaip negali įsitekti Rusija. Todèl tiktai platesnio masto tarptautinès institucijos yra pajęgios spręsti Baltijos saugumo dilemą ir vykdyti konfliktų prevencijos funkciją. 1991-1994 metais su šia užduotimi sėkmingai susidorojo - ESBK. ESBK buvo tas tarptautinis formatas, kuris užtikrino sẻkmingą Rusijos kariuomenès išvedimą iš Baltijos valstybių. Tačiau netrukus tapo aišku, kad ESBK mažai kuo gali pagelbėti toliau galutinai reguliuojant ir normalizuojant Baltijos valstybių ir Rusijos tarpusavio santykius. Prasidejjusị regioninị Šaltajj̨ karą galèjo užbaigti tiktai įtaka tokių tarptautinių institucijų, kurios yra pajegios lygiaverčiai bendrauti su Rusija. Tokia institucija ir tapo NATO. Iš pradžių sujungusi savo buvusias priešininkes ị NACC, po to į EAPC bei PfP programas, o 2002 metais apsisprendusi priimti ic savo gretas Baltijos valstybes, NATO sugebejo surasti ir dar ypatingą santykių institucionalizacijos su Rusijos formą. Todèl, galima sakyti, kad iš esmès saugumo režimas Baltijos jūroje iš esmès tampa NATOcentrišku režimu, nes netgi tos šalys, kurios formaliai nèra NATO narès, vis tiek bus užmezgusios solidžius ryšius su šia organizacija. Tai jau seniai galioja Suomijos ir Švedijos atžvilgiu ir pradeda galioti Rusijos atžvilgiu.
\end{abstract}

\section{Ivadas}

Nepaisant daugybės reikšmingų permainu Baltijos jūros regione ir atsinaujinančio saugumo sistemos dinamikos, visuotinai pripažįstama, kad Baltijos jūros regionas buvo ir išlieka viena stabiliausių vietų Europoje. Praeitame dešimtmetyje, liepsnojant kruviniems konfliktams buvusioje Jugoslavijoje, Baltijos regionas ne kartą reporterių buvo lyginamas su Balkanų regionu, norint pabrèžti, jog, nepaisant panašiai skambančiu regionų pavadinimų, neramūs Balkanai galètų daug ko pasimokyti iš stabiliosios Baltijos. Atrodo, kad šiandien jau turime gana išsamų atsakymą i klausimą, kodėl Balkanai yra tokie nestabilūs. Ši problema yra išnagrinèta labai išsamiai ir kruopščiai. Tuo tarpu klausimas, kodèl Baltijos regionas yra toks stabilus, aiškiai susilaukẻ daug mažiau dėmesio. Tai galima suprasti. Stabilumas nėra toks

"Prof., dr. Gediminas Vitkus - Lietuvos karo akademijos Politikos mokslų katedros vedejjas, Vilniaus universiteto Tarptautinių santykių ir politikos mokslų instituto docentas. Adresas: Šilo 5a, 2055 Vilnius, tel. 8-5-2127970, e-paštas: gediminas.vitkus@tspmi.vu.lt

${ }^{* *}$ Už paramą rengiant šị darbą autorius dékoja NATO-Euroatlantinės partnerystés tarybos tyrimų rèmimo programai. 
dalykas, kuris patenka ị laikraščiu pirmuju puslapių antraštes. Tačiau pažvelgus įdèmiau, aiškejja, kad regioninio stabilumo fenomenas ir yra, ko gero, ne mažiau į̇omesnè problema negu regioniniai konfliktai. Faktas, jog per paskutinị 20 amžiaus dešimtmetį Baltijos jūros regione ịvykusios grandiozinès permainos nepažeide egzistuojančio stabilumo, egzistuojančios konfliktinès įtampos neperaugo ị atvirus konfliktus ir jègos naudojimą, yra pakankama priežastis kelti klausimą, kas tą stabilumą palaiko ir kokie yra jo reprodukcijos mechanizmai bei tolesnès raidos perspektyvos.

Be abejonès, atsakymų į šį klausimą pirmiausia derètų ieškoti analitineje literatūroje, skirtoje Baltijos jūros regiono saugumo problematikai. Reikia pastebėti, kad apskritai tyrinètojų dèmesio Baltijos jūros regiono saugumo problematikai tikrai netrūksta. Per pastarajį dešimtmetį parašyta ir paskelbta galybè straipsnių ir knygų, surengta tiek mokslinių ir praktinių konferencijų, kurių tikslaus skaičiaus dabar turbūt jau nebeįmanoma nustatyti. Intensyviai Baltijos regiono studijos plètojosi tiek pačiose Baltijos jūros valstybèse, tiek ir kitų šalių mokslinių tyrimų centruose. Jeigu pažvelgsime į žinomiausių tyrimų centrų ir universitetų internetines svetaines, kur yra skelbiamos mokslinès publikacijos, neabejotinai aptiksime literatūros ir Baltijos jūros regiono saugumo tema ${ }^{1}$. Vis dažniau pasigirsta ir pačių mažiausiụjų Baltijos valstybių mokslininkų balsai ${ }^{2}$. Atsižvelgiant ị tai, kad aplink Baltijos jūrą yra išsidèsčiusių nemažai valstybių, tapo kone tradicija rengti tarptautines konferencijas ar tarptautinius projektus ir jomis remiantis leisti kolektyvines monografijas, kuriose yra pristatomos visų Baltijos jūros valstybių oficialios arba neoficialios ekspertų nuomonès įvairiais regiono saugumo klausimais ${ }^{3}$. Tiesa, reikia pastebèti, kad autoriniu monografijų mažiau. Tokių autorių skaičius yra proporcingas studijose aprépiamų šalių skaičiui. Jos labiau skirtos ne visam Baltijos jūros regionui, bet arba Skandinavijos, arba Baltijos valstybèms atskirai ${ }^{4}$.

\footnotetext{
${ }^{1}$ Daug naudingų nuorodų į tyrimų institucijas galima rasti JAV ambasados Stokholme interneto svetaineje: http://www.usemb.se/BalticSec/links.html; http://www.csm.org.pl/en_index.html

${ }^{2}$ Atrodo, kad Baltijos jūros regiono problematikos tyrinejimo lyderio tarp Baltijos valstybiu tyrimo institucijų vietą užima Latvijos tarptautinių santykių institutas (http://www.lai.lv). Vertingų nuorodu galima rasti ir Estijoje adresu: http://www.evi.ee/english/link.html.

3 Žr. pavyzdžiui: Wellmann C., ed., The Baltic Sea Region: Conflict or Cooperation? Region Making, Security, Disarmament and Conversion. Proceedings of the TAPRI-PFK-Workshop, Kiel, December 6-8,1991, Munster, Hamburg: Lit Verlag, 1992; Joenniemi P \& Vares P., eds., New Actors on the International Arena: The Foreign Policies of the Baltic Countries, Tampere: TAPRI, 1993 (Research Report, No. 50); Petersen N., eds., The Baltic States in International Politics, Copenhagen: DJØF Publishing, 1993; Arteus G., Lejins A., eds., Baltic Security. Looking towards the 21st century, Riga and Stockholm, 1997; Mouritzen H., ed., Bordering Russia: Theory and Prospects for Europe's Baltic Rim, Ashgate, 1998; Rotfeld A.D. ed., The New Security Dimensions. Europe After the NATO and EU Enlargements. Report of the Frosunda Conference, Frosunda, April 20-21, 2001, Stockholm: SIPRI, 2001; etc.

${ }^{4}$ Vis delto verta pamineti ir tokias publikacijas: Hidden J., Salmon P., The Baltic Nations and Europe. Estonia, Latvia and Lithuania in the Twentieth Century, revised edition, London and New York: Longman, 1995.; Knudsen O.F., „Cooperative security in the Baltic Sea region“, Chaillot Paper 33, Paris: Institute for Security Studies of WEU, 1998. Web edition - http://www.iss-eu.org/ chaillot/chai33e.html, 200206 01; Perry Ch. M., Sweeney M.J., Winner A.C., Strategic Dynamics in the Nordic-Baltic Region. Implications for US Policy, Brassaey's, 2000; Vaahtorana T., Forsberg T., „Post-Neutral or Pre-Allied? Finnish and Swedish Security Policies on the EU and NATO as Security Organizations“, Working Paper of the Finnish Institute of International Affairs, Helsinki, 2000, no. 29; Clemens W. C. Jr., The Baltic Transformed: Complexity Theory and European Security, Lanham: Rowman \& Littlefields Publishers, 2001.
} 
Taigi literatūros yra tikrai daug ir visų įmanomų šaltinių tiesiog neįmanoma aprèpti. Publikacijų Baltijos regiono saugumo tema gausa lemia ne tik visapusišką ir išsamų jos tyrinejjimo lygi, bet ir palieka mažai erdvès inovacijoms. Susipažinus su literatūra, susidaro įspūdis, kad būtų labai sunku ar netgi praktiškai neįmanoma, pasakyti ką nors naujo apie Baltijos jūros regiono saugumo problematiką. Nagrinejjami įvairiausi aspektai nuo „griežtojo“ (angl. hard) iki,,švelniojo“ (angl. soft) saugumo, nuo atskirų valstybių užsienio politikos iki viso regiono strateginio balanso ir dinamikos. Todèl, ko gero, Baltijos jūros saugumo problematikos tyrinètojo pastangas beveik galima būtų sulyginti su pastangomis atrasti Baltijos jūroje dar nežinomą salą.

Be abejo, šiandien vargu ar galima tikètis atrasti nežinomą salą Baltijos jūroje, bet, nepaisant visko, visada galima aptikti tam tikrų baltų dėmių mūsų sukauptų žinių visumoje. Ir jeigu kalbėsime jau konkrečiai apie minètą klausimą - kaip paaiškinti išskirtinị Baltijos jūros regiono stabilumą - tai tokių tyrinejjimų pasirodo nèra jau taip daug. Iš pačių naujausiujjų publikacijų galima paminèti Rikardo Bengtsono straipsnį $i^{5}$, kuriame autorius ieško atsakymo į klausimą, kokios jau yra ir kokių dar trūksta stabilios taikos regione sąlygų. Tačiau, nepaisant komplikuoto pačio stabilios taikos apibrèžimo, autoriaus išvada yra gana paprasta - ,analizė rodo, kad regione išsiplètojęs bendradarbiavimo schemų tinklas yra geras judejjimo link stabilios taikos pranašas" ${ }^{\text {"6 }}$. Taigi šis tyrimas buvo labiau orientuotas ị ateitį, siekiant įvardinti dabar egzistuojančias tendencijas.

I ateiti yra orientuotas ir, ko gero, stambiausias paskutiniais metais pasirodęs veikalas apie Baltijos jūros regioną. Tai Olaf F. Knudseno redaguota kolektyvinè monografija "Stability and Security in the Baltic Sea Region" " . Kadangi tai kolektyvinis darbas, tai jame aptariami labai ịvairūs Baltijos jūros regiono saugumo ir stabilumo aspektai, o pačią problemą bandoma analizuoti, remiantis įvairiomis teorinèmis prieigomis, tačiau, nepaisant bendro visus autorius vienijančio knygos pavadinimo, būtent pats Baltijos jüros regiono stabilumo fenomenas taip ir netapo tiesioginio tyrinèjimo objektu. İdomu pastebèti, kad nors knygos autoriai prieš pradėdami savo analizę paprastai neneigia, kad šis Baltijos jūros regionas yra pakankamai stabilus, tačiau vis dèlto pagrindinị dėmesị koncentruoja ị tai, kaip tą stabilumą dar labiau sutvirtinti. Kitaip tariant, daugumos tyrinètojų pasąmonejje tarsi užkoduota prielaida, kad regionas iš tikrujų nèra toks stabilus, kaip atrodo, ir kad tikrasis stabilumas dar turi būti pasiektas. Todèl minètoje knygoje, kaip ir daugybëje kitų publikacijų, tarsi nejučiomis yra siekiama normatyvinio tikslo - pateikti rekomendacijas, ką reikètų toliau daryti. Todèl nenuostabu, kad minètose studijose mes ir taip ir nerandame išsamesnio paties stabilumo fenomeno paaiškinimo. Atrodo, tam reikia platesnès analizès, kuri nagrinètų situacijos kaitą regione. Štai tokią analitinès literatūros spragą ir buvo siekiama užpildyti šiuo darbu.

Šio tyrimo pagrindinè prielaida, turejjusi padèti ieškoti atsakymo ị iškeltą klausimą - tai idejja, jog šiuo atveju Baltijos jūros regione egzistuoja labiau „giluminiai“ (angl. something behind) procesai, kurie tą stabilumą palaiko, nes niekas šiame re-

\footnotetext{
${ }^{5}$ Bengtson R., ,,Towards a Stable Peace in the Baltic Sea Region?“, Cooperation and Conflict, 2000, vol. 35 (4), 355-388.

6 "The analysis shows that the extensive web of cooperative schemes in place in the region shows the promise of a move towards stable peace". Ibid., 355.

${ }^{7}$ Knudsen O.F., ed., Stability and the Security in the Baltic Sea Region, London: Franc Cass, 1999.
} 
gione nesiekia visiškai igyvendinti savo interesus. Ir tas „kažkas“ yra ne kas kita, kaip tam tikrų elgsenos normų, kurias galbūt generuoja tam tikros tarptautinès institucijos, prisilaikymas. Šiuo atveju ne taip svarbu, kokie motyvai skatina regiono valstybes veikti taip, o ne kitaip. Svarbus yra pats faktas, kad tam tikrų normų ir taisykliu egzistavimą galime fiksuoti praktikoje. Štai šiame kontekste visai vertinga yra prisiminti jau klasikiniu tapusị tarptautinių režimų apibrěžimą, kurị dar 1988 metais suformulavo Stephenas Krasneris: „tarptautiniai režimai gali būti apibūdinti kaip visuma principų, normų, taisyklių ir sprendimų prièmimo procedūrų, aplink kurias susiformuoja atskiroje srityje veikiančių veikèjų lūkesčių konvergencija“8.

Jeigu sutiksime su prielaida, kad Baltijos jūros regione saugumo užtikrinimo klausimai daugiausia yra reguliuojami čia visiems veikejjams priimtinų normų ir elgsenos taisyklių ar konvencijų pagrindu, tuomet iš karto turèsime rimtą argumentą ir galėsime formuluoti hipotezę, kad Baltijos jūros valstybių regione per pastaraji dešimtmetị susiformavo arba ir toliau formuojasi apibrèžtas saugumo režimas, kuris ir palaiko tam regione fiksuojamą stabilumą.

Gal būt kiek abejonių gali kelti šios saugumo režimo sąvokos taikymas konkrečiam regionui. Tai iš tiesų yra problematiška, nes, kaip rodo atitinkamos literatūros analizè, yra praktiškai neįmanoma pateikti neginčijamą regiono definiciją. Bet šiuo atveju mes ir nesivadovavome geografiškai griežtu Baltijos jūros regiono apibrèžimu. Dẻmesio centre buvo ne vien tik konkrečiai prie Baltijos jūros esančios valstybès, bet ir visi kiti veikejjai, kurie vienaip ar kitaip, dèl vienokių ar kitokių priežasčiu buvo įsitraukę ar dar kaip nors susiję su pagrindinès konfliktinès linijos (t.y. Baltijos valstybiu ir Rusijos saugumo dilemos) valdymu ir reguliavimu. Todèl iš principo regione veikiantis tarptautinis saugumo režimas nebūtinai pats turi būti regioninis. Šiuo atveju mes kalbètumėme apie platesniame kontekste vyraujančio režimo regioninio veikimo specifiką.

Taigi šio tyrimo tikslas buvo pabandyti apibūdinti Baltijos regione besiformuojantị saugumo režimą, jo principų ir normų transformacijas per pastarajị dešimtmetị nuo Šaltojo karo pabaigos iki šių dienų, kada Baltijos šalys stovi ant NATO narystès slenksčio ir ryškėja nauji Vakarų ir Rusijos saugumo koegzistencijos kontūrai.

Jau pati „saugumo režimo“ "sąvoka tarsi apibrěžia ir pagrindinę projekto metodologinę prieigą, kuria rèmèsi tyrimas. Tai neoliberalusis institucionalizmas. Ši teorine prieiga ${ }^{9}$ susiformavo devintame dešimtmetyje kaip reakcija ị 1979 metais Kennetho Waltzo knygoje „Theory of International Politics“10 išplètotą neorealistinę tarptautinių santykių teoriją. Neoliberalusis institucionalizmas sutinka su neorealizmu, kad svarbiausią vaidmenị pasaulio politikoje vaidina valstybės ir jų galios pusiausvyra. Tačiau tuo pat metu ši mokykla pastebi, kad neorealizmas, akcentuodamas konkurencinį tarptautinės politikos pobūdį, pernelyg mažai teikia reikšmės fak-

\footnotetext{
8 „International regimes are defined as principles, norms, rules, and decision-making procedures around which actor expectations converge in a given issue-area“. Krasner, S.D., „Structural causes and regime consequences: regimes as intervening variables" in Krasner, S.D. ed., International Regimes, Ithaca and London: Cornell University Press, 1988, 2.

${ }^{9}$ Žr. pvz.: Axelrod, R., Evolution of Cooperation, New York: Basic Books, 1984; Oye, K., ed., Cooperation Under Anarchy: Princeton: Princeton University Press, 1986; Keohane, R.O., International Institutions and State Power: Essays in International Relations Theory, Boulder, CO: Westview, 1989.

${ }^{10}$ Waltz, K.N., Theory of International Politics, Reading (Mass.) etc.: Addison-Wesley Publishing Company, 1979.
} 
tui, jog valstybės ne tik varžosi, bet ir bendradarbiauja, ir netgi kuria tam tikras tarptautines normas, taisykles ir institucijas, kurios kartą priimtos arba įsteigtos pradeda veikti tų pačių valstybių politiką. Todèl, pasak neoliberaliojo institucionalizmo teoretiku, norint giliau suvokti tarptautinès politikos procesus, reikia gilintis ne tik i valstybių galios pusiausvyrą, bet ir atsižvelgti į egzistuojančias tarptautines institucijas ir jose įkūnytas tarptautinès elgsenos normas ir konvencijas. Gausios ir įvairiausio tipo tarptautinès institucijos ir organizacijos yra kuriamos tam, kad sujungtų valstybių pastangas, siekiant vienų ar kitų tikslų arba paprasčiausiai palengvintų tarpvalstybinị bendravimą, tačiau, kaip sako šios mokyklos atstovai, tam tikromis aplinkybèmis tarptautinès institucijos gali suvaidinti netgi lemiamą vaidmenį sprendžiant arba reguliuojant vieną arba kitą tarptautinės politikos problemą.

Pagaliau reikia pažymèti ir tai, kad greta principinés neoliberaliojo institucionalizmo prieigos darbe buvo remiamasi ir istorine analize, kurios pagalba buvo siekiama išskirti Baltijos jūros regioninio saugumo sanklodoje vykusių pokyčiu etapus ir specifiką bei apibūdinti principinių saugumo klausimais užsiimančių institucijų, visų pirma ESBO ir NATO evoliuciją. Pagrindiniai etapai, pagal kuriuos ir sukonstruota darbo struktūra, buvo išskirti pagal esminius pokyčius regioninio saugumo konsteliacijoje. Pirmasis etapas apima laikotarpị nuo Šaltojo karo pabaigos iki 1994 metų pabaigos, kada regione ir visoje Vidurio Europoje buvo intensyviai šalinamas Šaltojo karo palikimas. Antrasis etapas nuo 1995 metų iki 2001 metų iš esmès yra laikotarpis, kada svarbiausieji veikejjai Baltijos jūros regione dar negalëjo galutinai apsispręsti ir rinkosi sprendimą, kaip turètų atrodyti ateities saugumo režimas šioje Europos vietoje iš kelių siūlomų ir diskutuojamų alternatyvų. Pagaliau 2001 metus galima laikyti skiriamaja riba, kada Baltijos jūros regione galutinai ịsitvirtina NATOcentriškas saugumo režimas su dviem pagrindiniais ramsčiais, kuriuos sudaro subalansuotos NATO valstybių ir NATO partnerių grupès.

\section{1990 - 1994 metai: Šiaurès balanso demontažas}

Šaltojo karo metais Baltijos jūros regione griežta supergalybių ir jų sajungininkų konfrontacija derinosi su tam tikra specifika. Čia buvo susiklostęs gana savitas saugumo režimo modelis, kuris analitikų darbuose buvo vadinamas Šiaurès balansu. Tai reiškè, jog Baltijos jūros regione supergalybès ir jų sajungininkai konfrontuoja ne tiesiogiai kaip Vokietijoje, bet jų teritorijos yra atribotos neutralių buferinių valstybių - Śvedijos ir Suomijos. Ir netgi tụ pačiu minètų valstybių neutralitetas buvo skirtingas. Švedija, formaliai būdama neutrali, vis dèlto buvo susijusi daugybe neformalių saugumo ryšių su NATO ${ }^{11}$. Tuo tarpu Suomija 1948 metais buvo priversta pasirašyti jai nepalankią Draugystès, bendradarbiavimo ir tarpusavio pagalbos sutartị su Sovietų Sajunga. Pagal šios sutarties nuostatas, Suomija iš esmès turèjo apribotas galimybės vykdyti savarankišką nacionalinio saugumo politiką, nors mainais už ši apribojimą sovietai nesikišo į Suomijos vidaus politiką bei paliko galimybę Suomijai su likusia Europa savarankiškai plètoti ekonominius ir kultūrinius ryšius. Taigi šia-

\footnotetext{
${ }^{11}$ Išsamiau žr.: Vaahtorana T, Forsberg T., "Post-Neutral or Pre-Allied? Finnish and Swedish Security Policies on the EU and NATO as Security Organizations" Working Papers of the Finnish Institute of International Affairs, Helsinki, 2000, no. 29. pp. 7-9
} 
me regione egzistavo ir kiek kitokios negu Vidurio Europoje „nerašytos“ saugumo užtikrinimo normos ir taisyklès, kuriomis niekas perdaug nebuvo patenkintas, bet tuo pat metu niekas nenorejo arba negalëjo jų kaip nors iš esmès keisti.

Dinamiškas pokyčiu po Šaltojo karo regione procesas ir globalinės konfrontacijos pabaiga iš esmès pakeite pagrindines potencialių tarpvalstybinių konfliktų linijas ir Baltijos jūros regione. Pagrindiniu konfliktų mazgu ir saugumo dinamikos šaltiniu regione tapo naujai atsikūrusių Baltijos valstybių - Lietuvos, Latvijos ir Estijos - ir Rusijos santykiai. Galbūt ši konfliktinẻ linija ir nebūtų tokia reikšminga, jeigu ne toks didžiulis mažŭ Baltijos respublikų ir Rusijos galios potencialų skirtumas ir ne ypatinga, trukdanti Rusijai išeiti į Baltijos jūrą, Baltijos valstybių geopolitiné padètis. Baltijos valstybių saugumas visada yra problema vien jau dél to, kad Baltijos regionas Rusijai visada buvo ir liks strategiškai svarbiu. Rusija, nepaisant to, kad jos interesai yra žymiai platesni ir negali būti sukoncentruoti vien šiame regione, vis dèlto dẻl daugelio priežasčių nenori ir negali pasitraukti iš čia. Todèl Rusijos ir Baltijos valstybių santykiai visų pirma dèl iš esmès besiskiriančių šių valstybių požiūrių į saugumo problemą visą dešimtmetį kẻlè ir turètų toliau kelti įtampą regione. Todèl į šią įtampą neišvengiamai turèjo reguoti ir kitos regiono valstybès bei atitinkamos tarptautinès institucijos. Būtent todèl aplink šią konfliktinę ašį ir pradèjo formuotis naujasis Baltijos jūros regiono saugumo režimas.

\subsection{Svarbiausi pokyčiai Baltijos jūros regione po Šaltojo karo}

Permainos Baltijos jūros regione, skirtingai nuo Vidurio Europos, prasidejo šiek tiek vèliau. Jeigu 1989 metų pabaigoje beveik visos Vidurio Europos valstybès jau buvo išsivadavusios nuo komunistų valdžios ir atkūrusios savo suverenitetą, tai Baltijos jūros regione artejjančias permainas liudijo nacionalinio išsivadavimo judejjimai trijose dar Sovietų Sajungos kontroliuojamose respublikose -Estijoje, Latvijoje ir Lietuvoje. Tačiau Maskva, nepaisant fundamentalių jos laikysenos pasikeitimų tarptautinėje arenoje, né neketino atsisakyti šių trijų respublikų kontrolès. Ir netgi Suomijos, kurios suverenitetas buvo suvaržytas 1948 metų Draugystės, bendradarbiavimo ir abipusės pagalbos sutartimi, klausimas kol kas nebuvo garsiai svarstomas, nors 1990 metais igyvendintas Vokietijos susivienijimas iš esmès jau reiškè, kad tiek Vokietijos, tiek ir jos buvusių sajungininkų suvereniteto apribojimai turètų būti galutinai pašalinti. Todèl pats svarbiausias Baltijos jūros regionui pokytis, kuris dave galingą impulsą fundamentalioms permainoms, žinoma, buvo ne Michailo Gorbačiovo politika, kuria buvo siekiama užbaigti konfrontaciją su JAV ir jos sajungininkais, bet pačios Sovietų Sajungos suirimas 1991 metų pabaigoje. Šios valstybės išnykimas iš politinio žemėlapio ne tik pakeite geopolitinę situaciją, bet ir atvère visiškai naujas galimybes, apie kurias niekas anksčiau per daug ir negalvojo.

Kaip tik dèka šio esminio pokyčio per 1991-1994 metus Baltijos jūros regionas pasikeite neatpažistamai. Visos regiono valstybès, kaip ir visoje Vidurio ir Rytų Europoje, atgavo laisvę ir suverenitetą ir įgijo galimybę nustatyti tokius tarpusavio santykius, kokie joms atrodè reikalingi. Todèl daug kas priklausė nuo to, kokią orientaciją pasirinks ir kokią saugumo politiką vykdys išorinių apribojimų nebevaržomos valstybių vyriausybès. Štai jau 1991 metais viena svarbiausių regiono valstybių Švedija - apsisprendè stoti ị Europos Bendriją ir ịteikẻ Europos Komisijai atitinkamą paraišką, o 1992 metų gegužès mènesį Švedijos parlamentas atšaukè ilgaamžị Švedijos užsienio politikos principą - neutralitetą ir paskelbè, jog tik karo atveju 
Švedija liks neutrali. Tai atvėrè galimybę Švedijai taikos metu dalyvauti bendradarbiauti su kitomis šalimis ir organizacijomis ne tik sprendžiant saugumo klausimus, bet ir siekti narystès Europos Bendrijoje.

Svarbūs pokyčiai vyko ir kitos labai svarbios regionui Vidurio Europos valstybės - Lenkijos - saugumo politikoje. Šaltojo karo metais ši šalis saugumo požiūriu buvo atsidūrusi labai dviprasmiškoje situacijoje. Jos suverenitetas buvo iš esmès apribotas ne tik Sovietų Sajungos galios, bet ir Sovietų Sajungos teikiamų saugumo garantijų. Po Antrojo pasaulinio karo Lenkijos igytos vakarinès teritorijos buvo savotiška kompensacija jai už prarastas rytines žemes, kurios šiandien įeina į Ukrainos, Baltarusijos ir Lietuvos sudètį. Tačiau kartu su vakarinėmis „atgautomis“žemèmis Lenkija ịijo ir grèsmę, kad, pasikeitus tarptautinei situacijai ir susivienijus Vokietijai, dalis jos teritorijos vel gali tapti Vokietijos pretenzijų objektu. Todèl regiono stabilumui ypač reikšminga, kad Lenkija su savo kaimynais - Vokietija bei Ukraina, Baltarusija ir Lietuva - sureguliuotų savo santykius be jokių tarpininkų. Tą pavyko Lenkijai pasiekti iki 1994 metų.

Tačiau svarbiausias dalykas, kurị pirmiausia norejo užsitikrinti Baltijos jūros regiono valstybės po Sovietų Sajungos suirimo - tai, be abejonès, galutinai negrį̌tamai demontuoti buvusį sovietinị dominavimą rytinèje Baltijos jūros pakrantèje liudijančius reliktus. Suomijos atveju - anksčiau minèta 1948 metų sutartis, o Estijos, Latvijos ir Lietuvos atveju-Rusijos kariuomenės išvedimas.

1948 metų Suomijos ir Sovietų Sajungos Draugystès, bendradarbiavimo ir abipusès pagalbos sutartis turëjo galioti dešimt metų, o 1955 metais perrašyta taip, kad galiotų dvidešimt metų. Sutarties galiojimas buvo pratęstas 1970 ir 1983 . Ir netgi 1991 metų kovo mėnesį, kaip visada, buvo paminètos jau 43-osios sutarties galiojimo metinès. Taigi nepaisant esminių pokyčiu Europos viduryje, panašu ị tai, kad Sovietų Sajunga buvo linkusi absoliučiai nieko nekeisti ir išlaikyti jai palankų Šiaurès balanso režimą Baltijos jūros regione. Ir tiktai 1991 metų rugpjūčio mènesio komunistinio pučo Maskvoje nesėkmė lèmè, kad ir Baltijos jūros regione Sovietų Sajungai nepavyks sustabdyti permainų. Pagrindinis Suomijos interesas, derintis dèl šios sutarties, be abejonès, buvo noras panaikinti bet kokią užuominąi ankstesnę 1948 metų sutartị ir siekis, kad ši sutartis netgi nebūtų paminèta naujos sutarties tekste. Pasak Suomijos derybininko Jaakko Blombergo:

[...] taigi sunkus Draugystès, bendradarbiavimo ir abipusès pagalbos sutarties palikimas buvo palaidotas be didesnio triukšmo, o naujojoje sutartyje nebebuvo jokių dvišalių saugumo politikos įsipareigojimų, kurie peržengtų visoms Europos šalims pagal galiojančias bendrąsias privalomų įsipareigojimų ribas ${ }^{12}$.

Todèl savotišku pagrindu naujai sutarčiai tapo ne komplikuota Suomijos ir Rusijos santykių istorija, bet tokie daugiašaliai tarptautiniai susitarimai kaip Jungtinių Tautų Chartija bei Europos saugumo ir bendradarbiavimo konferencijos Helsinkio Baigiamasis aktas ir Paryžiaus chartija su juose užfiksuotomis valstybių elgsenos normomis. Kitaip tariant, Suomija siekè ir norėjo naujus santykius su Rusija kurti naujais, platesniais negu ankstesni dvišaliai, pagrindais ir taip galutinai nutraukti liūdną praeities ,specialiųjų“ santykių su Rusija praktiką.

${ }^{12},[\ldots]$ all in all, the difficult heritage of the FCMA treaty was buried without an notable discord and the new treaty included no special bilateral security policy obligations that go beyond those binding all European States already on the basis of agreed-upon general conventions." Cituojama pagal Pursiainen C., „Finland's Policy Towards Russia. How to Deal With the Security Dilemma?“, Northern Dimensions 2000. Yearbook of the Finish Institute of International Affairs, Helsinki, 2000, 70 . 
Sovietų Sajungos suirimas ir nepriklausomų Baltijos valstybių atsiradimas turbūt buvo vienas iš esminių permainų, pakeitusių visą geostrateginę situaciją Baltijos jūros regione. Jeigu Sovietų Sajunga buvo viena iš dominuojančiu galių Baltijos jūros regione, tai jos teisių ir palikimo paveldètojai - Rusijos Federacijai - teliko mažai reikšmingos Baltijos jūros pakrantès valdos - Kaliningrado eksklavo ir Sankt Peterburgo regiono pakrantès. Bet toks situacijos pasikeitimas iš esmès formavo visiškai naują tarp Baltijos valstybių ir Rusijos konfliktą ir grèsmę regioniniam saugumui. İtampą kèlè ne tiek tiesioginè Rusijos karinès intervencijos galimybè. Naujoji Rusijos valstybė ir jos politinė vadovybe், vien jau atsižvelgiant ị ankstesnę tarpusavio santykių raidą, kuomet Rusijos politikai siekè pasinaudoti Baltijos valstybèmis savo konkurencijoje su Sovietų Sajungos lyderiais, nebegalëjo ginčyti pačio Baltijos valstybių nepriklausomybės fakto. Tačiau, suirus Sovietų Sajungai ir jos vietą užèmus Rusijai, neišvengiamai turejo pasikeisti ne tik Baltijos valstybių ir Rusijos santykių teisine forma, bet ir pats dvišalių santykių turinys. Nors dèl Baltijos valstybių nepriklausomybès niekas nesiginčijo, bet faktinių jų santykių su Rusija status quo parinkimo galimybės 1991 metų pabaigoje buvo pakankamai didelès. Baltijos valstybėse tebebuvo Rusijai pavaldžios karinès pajëgos, naujujų valstybių ekonomika buvo visiškai integruota į buvusios Sovietų Sajungos ekonominę erdvę, Baltijos šalyse (ypač Latvijoje ir Estijoje) gyveno daug sovietinės okupacijos metais imigravusių rusų tautybės asmenų, kurie, suirus Sovietų Sajungai, niekur neišvykę, staiga atsidūrè užsienyje. Todẻl visiškai natūralu, kad šiuo laikotarpiu Baltijos šalims ir Rusijai reikèjo sureguliuoti ir išspręsti daugybę klausimu, susijusių su Sovietų Sajungos paveldo demontavimu.

Regioninio saugumo požiūriu, be abejonès, čia, kaip ir Vidurio Europos šalyse, svarbiausia problema buvo Rusijai pavaldžios kariuomenès išvedimas ir tarpvalstybinių sienų, kuriomis tapo administracinès buvusių sovietinių respublikų ribos, įteisinimas. Tačiau, kaip netrukus paaiškèjo, Baltijos valstybėms susitarti dèl minètų dalykų su Rusija sekèsi gana sunkiai. Rusijos nenoras greitai tartis buvo sąlygotas tiek objektyvių, tiek ir subjektyvių priežasčių. Rusijai reikejjo vykdyti kariuomenės išvedimo iš Rytų Vokietijos ir Lenkijos įsipareigojimus. Be to, išvedamą kariuomenę reikèjo ịkurdinti naujose dislokacijos vietose, kurios ir taip jau buvo perpildytos arba iš viso neįrengtos. Rusija paveldèjo milžinišką Sovietų Sajungos kariuomenę, kuri kẻlẻ itampą visam demokratiniam pasauliui, bet buvo aiškiai per didelè jos pačios gynybos reikmèms. Kaip tik dèlto Rusijos vyriausybe turèjo būti suinteresuota bent jau iš Baltijos valstybių kariuomenès išvedimą vilkinti kiek įmanoma ilgiau. Todèl derybų pradžioje apie kariuomenès išvedimo datą buvo nekalbama, o vèliau, kaip išvedimo pabaiga, buvo pradèti minèti $1997-1999$ metai $^{13}$.

\footnotetext{
${ }^{13}$ Pirmosios Rusijos ir trijų Baltijos valstybių derybos dèl kariuomenés išvedimo vyko $1992 \mathrm{~m}$. sausio 31-vasario 2 d. Derybose su Lietuva ir Latvija buvo susitarta, kad kariuomenè pradès kraustytis iš šių šalių jau vasario mènesį. Tačiau nepavyko susitarti dèl jokių galutinių išvedimo datų. Šiuo klausimu derybos neatnešė apčiuopiamų rezultatų. 1992 metu gegužès 4-7 dienomis Rusijos užsienio reikalu ministro pirmasis pavaduotojas Fiodoras Šelov-Kovediajevas, lydimas delegacijos, kurią įejo ir Rusijos kariuomenès Šiaurès-vakarų grupès vadas, generolas pulkininkas Valerijus Mironovas, apsilankė Estijoje, Latvijoje ir Lietuvoje. Atsakydama ị Baltijos šaliu reikalavimą nedelsiant išvesti kariuomenę, Rusijos pusė pakartojo, kad buvusios sovietų kariuomenės išvedimas iki 1997-1999 metų yra neįmanomas dèl kariškių materialinio aprūpinimo problemų.
} 
Taigi Baltijos valstybių politinė vadovybė svetimos kariuomenės išvedimo problemą greitai išspręsti galëjo tik, kiek įmanoma iš karto ją internacionalizuodamos ir paversdamos visos tarptautinès bendrijos problema. Čia Baltijos valstybès, būdamos svarbiausiųjų tarptautinių organizacijų -JTO ir ESBK - narėmis, turẻjo nemažas galimybes.

Griežta Rusijos kariuomenès išvedimo problemos internacionalizacijos linija buvo tokia Baltijos valstybių taktika, kuri atnešè joms ne tik sẻkmę, bet ir tam tikrus kaštus. Šių šalių dvišaliai santykiai su Rusija taip pablogèjo, kad jų santykius buvo galima pavadinti netgi savotišku regioniniu „Šaltuoju karu“. Konflikto priežastimi tapo rusakalbių gyventojų teisinis statusas Latvijoje ir Estijoje. Iš trijų Baltijos valstybių Latvija ir Estija turejo daug didesnes rusakalbių gyventojų proporcijas ${ }^{14}$. Todèl Lietuvoje dèl daug palankesnès demografinès padèties rusakalbiai gyventojai pagal pilietybès įstatymą niekaip nebuvo diskriminuojami ir apsisprendę be kliūčių galėjo gauti Lietuvos pilietybę. Tuo tarpu Estijoje ir Latvijoje padètis buvo visiškai kitokia. 1992 metų vasarą Rusijos pareigūnai kariuomenès išvedimo klausimą pradèjo sieti su rusų etninès mažumos teisių problema. Be to, Rusija igijo galimybę sieti savo kariuomenès išvedimą ne tik su rusakalbiu padètimi minètose respublikose, bet ir, atsakydama Baltijos šalių pastangas internacionalizuoti kariuomenès išvedimo problemą, savo ruožtu siekti ir rusakalbių padèties Latvijoje ir Estijoje teisių klausimo internacionalizacijos. Jau 1992 metais Rusija kreipesi į Europos Tarybą ir ESBK, kad šios atkreiptų dèmesị ị rusakalbių žmogaus teisių padètį Baltijos valstybèse.

Prasidèjęs 1992 metais Rusijos „Šaltasis karas“su Latvija ir Estija neleido sudaryti Rusijos kariuomenès išvedimo sutarčių, todẻl Rusija išvedinëjo iš šių šalių savo kariuomenę savo nuožiūra. Tiktai 1994 metų balandžio 30 d. Latvijos ir Rusijos prezidentai pasirašè sutartị, pagal kurią turëjo būti išvesti likę 10000 Rusijos kariškių. Tačiau Rusijos techninis personalas (500-600 asmenų) dar turëjo likti Skrundos radarineje stotyje iki tol, kol ši bus uždaryta. $1994 \mathrm{~m}$. liepos mènesį Maskvoje Borisas Jelcinas su Estijos prezidentu Lenartu Meriu susitare dèl likusių 2000 Rusijos kariškių išvedimo. Pagal atskirą susitarimą apie 200 rusų specialistų turèjo likti buvusioje Rusijos povandeninių laivų bazėje Paldiskyje ir su civilių priežiūra turejo galutinai ją demontuoti iki 1995 metų rugsèjo mèn. Taigi oficialiai paskutiniai Rusijos koviniai junginiai paliko Estiją ir Latviją 1994 metų rugpjūčio 29 d.

\subsection{Stabilizuojantis tarptautiniụ institucijụ vaidmuo 1991-1994 metais}

Kaip jau galejome pastebėti, vykstant svarbiems geopolitiniams pasikeitimams regione ir formuojant naujus regiono valstybių santykių pagrindus, svarbią, o kartais ir lemiamą reikšmę turejo regione veikusių tarptautinių institucijų, ypač ESBK įtaka. Suomijos atveju, ESBK tiesiogiai nebuvo ịtraukta, bet ESBK dokumentų normos tapo pagrindu naujai tarpvalstybinių santykių sutarčiai su Rusija. Tuo tarpu sprendžiant Baltijos valstybių ir Rusijos santykių dilemas, ESBK vaidmuo, išlaikant stabilumą regione, daugeliu atveju buvo lemiamas. ESBK poveikis neabejotinai skatino Rusiją pakeisti savo poziciją dẻl kariuomenès išvedimo iš Baltijos valstybių ir apsispręsti užbaigti ši procesą 1994 metais drauge su likusios kariuomenès išvedimu iš Vokietijos ir Lenkijos.

${ }^{14}$ Pagal tuometinius gyventojų surašymų duomenis etniniai rusai sudare 8,7 proc. Lietuvos gyventojų, kai Estijoje jų buvo 28 proc., o Latvijoje net 30,4 proc. 
ESBK, o tai pat ir Europos Tarybos stabilizuojantis vaidmuo padejo suvaldyti bekylantį Rusijos konfliktą su Latvija ir Estija dèl rusakalbių gyventojų padèties. Rusija tikèjosi, kad internacionalizuodama ši klausimą ji pasieks, kad tarptautinès institucijos privers Latviją ir Estiją suteikti pilietybę visiems šalyje gyvenantiems gyventojams, tačiau, kaip paaiškejo vèliau, tarptautinè bendruomenè, nors ir linkusi tarpininkauti siekiant sureguliuoti rusakalbių padètị, vis dèlto atmeta idèją susieti tautinių mažumų klausimą su kariuomenès išvedimu. Didelės užsienio tikrintojų delegacijos ir stebėtojų misijos neaptiko rimtų žmogaus teisių pažeidimų Latvijos ir Estijos pilietybès ir natūralizacijos įstatymuose. Todèl galima tvirtinti, kad būtent dèl tarptautinių institucijų poveikio Rusijos pastangos internacionalizuoti etnines problemas Estijoje ir Latvijoje sukūrè situacija, kurią interesų balanso požiūriu galima vertinti kaip palankesnę Baltijos šalims ${ }^{15}$.

Taigi nuo 1991 iki 1994 metų Baltijos jūros regione kone svarbiausias vaidmuo, nustatant valstybių santykiu taisykles ir normas saugumo santykių srityje, neabejotinai priklausė ESBK. Tuo tarpu kitos Europoje aktyvios ir jo saugumui tarptautinės institucijos - NATO ir Europos Bendrija - buvo labiau susikoncentravusios į vidinius persitvarkymo procesus ir nesièmé aktyvesnio vaidmens regiono saugumo klausimuose. 1992 metais Europos Bendrijos šalys, norinčios pagilinti integraciją ir praturtinti ją politine ir ekonomine bei pinigų sajunga, susidūrẻ su Mastrichto sutarties ratifikacijos krize, kurią pavyko įveikti tiktai 1993 metais. Todèl Baltijos valstybių bandymas iškelti Rusijos kariuomenès išvedimo problemą Europos Bendrijos valstybiu - Danijos ir Vokietijos -inicijuojamoje Baltijos jūros valstybiu taryboje patyre nesėkmę ${ }^{16}$.

Ypatingo aktyvumo ar noro dalyvauti Baltijos jūros regiono saugumo klausimuose nerodè ir NATO, kuri taip pat išgyveno permainų ir prisitaikymo prie naujų sąlygų bei naujojo dialogo su buvusiomis priešininkėmis užmezgimo per NACC laikus. Tačiau NATO vis dèlto neatsiribojo nuo regiono saugumo problemų ir davė suprasti, kad ketina ir čia turèti "stabilizuojančią įtaką". 1992 metų kovo 11-16 d. NATO generalinis sekretorius Manfredas Wörneris aplankè Lenkiją, Lietuvą, Latviją ir Estiją. Kelionės metu jis akcentavo, jog NATO neleis Rytų Europoje atsirasti ir išsiplètoti „,saugumo vakuumui“. Jis pabrěžè, kad visos regiono šalys turètų pajusti stabilizuojančią NATO ịtaką, bet tuo pat metu ịspejjo, kad Aljansas negalès pasiūlyti formalių saugumo garantijų ar tuo labiau galimybès ịstoti $\mathrm{i}$ jị.

Tačiau jeigu ESBK ir pasirodẻ kaip organizacija, kuri sugeba reguliuoti saugumo klausimus ir ịgyvendinti konfliktų prevenciją pakankamai ramiomis aplinkybè-

\footnotetext{
${ }^{15}$ Žr.: Norkus R., „Preventing Conflict in the Baltic States: A Success Story That Will Hold?“ in Bonvicini G, et al., eds., Preventing Violent Conflict. Issues from the Baltic and Caucasus, BadenBaden: Nomos, 1998, p. 153.

${ }^{16} 1992$ metų kovo 5-6 d. 10 Baltijos jūros valstybių užsienio reikalų ministrai susirinko Kopenhagoje ir susitare įsteigti Baltijos jūros valstybių tarybą. Ši Danijos ir Vokietijos iniciatyva jungè Daniją, Estiją, Latviją, Lietuvą, Lenkiją, Norvegiją, Rusiją, Suomiją, Švediją ir Vokietiją. Jos tikslas buvo sukurti bendriją, kuri padètu trims Baltijos šalims, Lenkijai ir Rusijai greičiau tapti rinkos ekonomikos šalimis. Tačiau susitikimo metu Danijos užsienio reikalų ministras ir susitikimo pirmininkas Uffe Ellemannas-Jensenas pabrėžè, kad Taryba veiks glaudžiai bendradarbiaudama su egzistuojančioms Europos organizacijomis. Jis teige, kad Baltijos regionas ateityje taps Europos Bendrijos vidiniu regionu, ir toks regioninis bendradarbiavimas turetu jau dabar sustiprinti Europos Bendrijos ryšius su dar šiai organizacijai nepriklausančiomis regiono valstybėmis. Kovo 6 d. Estijai, Latvijai ir Lietuvai pabandžius iškelti Rusijos kariuomenès išvedimo iš jų teritorijos vélavimo klausima, Ellemennas-Jensenas pabrěžè, kad Tarybos darbas neturètụ dubliuoti egzistuojančiu tarptautinių organizacijų darbo ir kad saugumo reikalai nepatenka ị šios naujai steigiamos Tarybos užduočių sąrašą.
} 
mis, tačiau krizès atvejais, kada reikia veikti labai greitai arba netgi panaudoti jègą norint suvaldyti konfliktuojančias puses, ESBK pasirodė beveik bejègè. ESBK nesẻkmingai bandè suvaldyti Jugoslavijos suirimo procesą, labai sunkiai sekèsi spręsti konfliktų prevencijos problemas Moldavijoje, Kaukaze ir Užkaukazeje.

Todèl natūralu, kad Vidurio ir Rytų Europos valstybės, kurios jau buvo sèkmingai atkūrusios savo suverenitetą, vis dèlto jautè tam tikrą saugumo deficitą ir buvo linkusios ieškoti solidesnių saugumo garantijų, negu tai, ką galèjo pasiūlyti ESBK. 1992 metais atsirado požymių, jog buvusios Varšuvos pakto šalys iš Vidurio Europos yra likusios siekti narystès NATO ir tai traktuoja kaip kertinį jų „,sugrį̌imo ì demokratinę Europą“" politikos siekị.

Taip 1993 metų pabaigoje galimos NATO plètros į Vidurio Europą klausimas ir kategoriška Rusijos opozicija tapo kone labiausiai diskutuojamu politinès darbotvarkès klausimu. İtampą dar labiau padidino spalio mènesį Maskvoje vykęs ginkluotas konfliktas tarp prezidento ir sukilusio parlamento šalininkų. Galiausiai netikẻti Rusijos naujo parlamento rinkimų rezultatai, kur daugumą gavo rusų ultranacionalisto Vladimiro Žirinovskio vadovaujama „Liberalų-demokratų partija“ ir komunistai, paskatino net trijų Baltijos valstybių lyderius, susirinkusius gruodžio $13 \mathrm{~d}$. Taline pareikšti, kad jų šalys prašo NATO padèti užtikrinti jų šalių saugumą. Atsižvelgiant ị susiklosčiusią situaciją, NATO šalims reikejo apsispręsti ir duoti atsaką tiek pageidaujančioms įstoti šalims, tiek ir Rusijai šiuo aktualiu daugelio šalių saugumui klausimu.

Tačiau šį kartą buvo apsispręsta NATO plètrą vykdyti lètai, natūralia evoliucija, kuri prasidètų nuo ribotos apimties gynybinių susitarimų su atskiromis Vidurio ir Rytų Europos šalimis. ${ }^{17}$ Kaip žinia, 1994 metų sausio mènesio NATO viršūnių susitikimas Briuselyje patvirtino ši planą ir pavadino ji „Taikos partneryste“ (angl. Partnership for Peace - PfP).

PfP tapo labai svarbiu saugumo situacijos stabilizacijos Rytų Europoje instrumentu, kurio reikšmė nuolat didejjo. Nors 1994 metais ir buvo nuspręsta iggyvendinti ESBK reformą ir nuo 1995 metų pertvarkyti ją i Europos saugumo ir bendradarbiavimo organizaciją (ESBO), bet jos vaidmuo ir reikšmè bent jau Baltijos jūros regione tolydžio mažejo, nes ši ị konfliktų prevenciją ir valdymą orientuota organizacija neturejjo reikalingų priemonių ir negalèjo atsiliepti ị regiono valstybių saugumo stiprinimo poreikius. Tuo tarpu PfP, nors iš esmès ir nepretendavo pakeisti arba išstumti ESBO, bet neišvengiamai tapo svarbiu kontekstu, kuriame NATO stabilizuojantis poveikis pasidarè daug labiau juntamas negu iki tol. Čia svarbu tai, kad Taikos partnerystès Rèminiame dokumente buvo aiškiai pasakyta, kad:

NATO konsultuos kiekvieną aktyvų Partnerystės dalyvị, jei patirs, jog Partneris jaučia tiesioginę grèsmę savo teritoriniam vientisumui, politinei nepriklausomybei ar saugumui ${ }^{18}$.

171993 m. spalio 20-21 d. Travemiundèje po neformalaus NATO šaliu gynybos ministru susitikimo JAV gynybos sekretorius Lesas Aspinas paneigé, kad naujų narių priemimas nukeltas ị ateitị dẻl Rusijos veiksnio. Aspinas sake, kad naujų narių priemimo klausimas buvo svarstomas ne Rusijos grasinimų, bet JAV pasiūlymo sudaryti tarp NATO ir atskirų Rytų Europos šalių riboto įsipareigojimo saugumo susitarimų, t.y. „Taikos partnerystę“ kontekste. Pabrèždamas šio plano, kuriam buvo vienbalsiai pritarta, privalumus, Aspinas sakè, kad jo igyvendinimas padès pamatus kariniam bendradarbiavimui ir galimai naujų narių integracijai i NATO ateityje.

18 „NATO will consult with any active participant in the Partnership if that Partner perceives a direct threat to its territorial integrity, political independence, or security“. NATO, Partnership for Peace: Framework Document issued by the Heads of State and Government participating in the Meeting of the North Atlantic Council, Brussels, January 10, 1994, http://www.nato.int/docu/basictxt/ b940110b.htm (žiūrèta 20020601 ). 
PfP programa ir Rusijos įstojimas ị ją iš esmès užbaigè senojo saugumo režimo demontavimo procesą ir reiškè, kad Vidurio ir Rytų Europoje pradeda formuotis nauja saugumo situacija. Baltijos jūros regionui ypač reikšmingas buvo Švedijos ir Suomijos apsisprendimas įsijungti PfP. Taip ir Baltijos jūros regione 1994 metu pabaigoje be ESBK pagrindinių dokumentų dar vienu vienijančiu veiksniu tapo ir PfP, kur dalyvauja visos be išimties regiono šalys. Todèl tam tikra prasme galima sakyti, kad Taikos partnerystès Rèminis dokumentas tarsi tapo dokumentu, kuriame surašytos svarbiausios Baltijos jūros regione susiklosčiusio saugumo režimo normos ir taisyklès. Tačiau, iš kitos pusès, galima sakyti, kad 1994 metų pabaigoje, ǐ̌vedus Rusijos kariuomenę iš Baltijos valstybių ir Lenkijos bei pradejjus igyvendinti PfP, Baltijos jūros regionas išviso galutinai prarado savo Šaltojo karo metais atsiradusią specifiką ir tapo neatsiejama platesnès saugumo sistemos dalimi. Tačiau tolesnè ịvykių raida parodè, kad tai būtų gana skubota išvada, nes tiek Baltijos jūros regiono, tiek ir visos Europos saugumo sistema vis dèlto dar nebuvo baigta formuoti vien jau dèl to, kad Baltijos valstybiu ir Rusijos santykiai dar nebuvo iki galo normalizuoti. 1992 metais prasidejęs šių šalių Šaltasis karas su kariuomenès išvedimu toli gražu nesibaigè.

\section{Uždaras nesaugumo ratas $1995-2000$ metais}

1995 metai yra tam tikra prasme lūžio metai Baltijos jūros regiono saugumo sistemos raidoje, nes išvedus iš Lenkijos ir Baltijos valstybių Rusijos kariuomenę, pagrindinè konfliktinė linija, kelianti grèsmę viso regiono saugumui, igijo naują kokybę. Pagrindine nesutarimų ir ịtampos priežastimi tapo vienareikšmiškas Lenkijos ir trijų Baltijos valstybių apsisprendimas užtikrinti savo saugumą ir tai susieti su būsima naryste Šiaurès Atlanto sutarties organizacijoje. Tuo tarpu Rusija laikèsi nuostatos, kad Baltijos jūros regionas ir taip yra pakankamai saugus. Nẻ viena valstybẻ kariniu požiūriu nesudaro pavojaus kitai, todèl NATO plètra yra iš esmès nereikalingas ir provokacinis žingsnis, kuriam reikia priešintis. Tai, ko gero, ir buvo pagrindinis veiksnys, kuris Baltijos valstybių ir Rusijos santykius iš esmès komplikavo ir po to, kai iš šiu trijų valstybių buvo išvesta okupacinẻ Rusijos kariuomenè. Nors pasaulyje pasibaige Šaltasis karas, bet Baltijos jūros regione ir toliau vyko mažasis „Šaltasis karas“, kuris prasidèjo dar 1992 metais. Todèl saugumo atmosferos būklè visame regione turèjo priklausyti nuo to, kaip toliau plètosis Rusijos ir jos buvusių valdinių saugumo santykiai.

\subsection{Rusijos ir Baltijos valstybiụ santykiụ aklavietė}

Kol sprendimas dèl NATO plètros į Baltijos jūros regioną nebuvo priimtas, Rusija savo pareiga laikė imtis visų priemonių, kad toks scenarijus niekada netaptų realybe. Šioje Rusijos politikoje galima išskirti dvi pagrindines kryptis. Pagrindinè kryptis buvo siekimas sukompromituoti Baltijos šalis NATO valstybių akyse, kaip šalis, kurios nėra tinkamos narystei bloke. Galima paminèti pagrindines tokios politikos priemones:

- reikalavimą pagerinti rusakalbių gyventojų Estijoje ir Latvijoje padėtį, nurodant, kad šių šalių nenoras, o tiksliau nesugebejjimas integruoti ị savo visuomenę rusakalbių bendruomenę, kelia abejonių dẻl jų demokratiškumo ir pagarbos mažumų teisèms; 
- atsisakymą galutinai sureguliuoti tarpvalstybinių sienų klausimą. Rusija 1997 metais tiktai su Lietuva yra pasirašiusi tarpvalstybinès sienos sutartį. Tačiau iki dabar (t.y. 2003 metų vidurio) ši sutartis neratifikuota ir negalioja, todèl Lietuvos ir Rusijos (Kaliningrado regiono) siena iš esmès tebėra laikina. Laikinų sienų statusą turi ir Rusijos sienos su Latvija ir Estija, nes tarpvalstybinès sutartys iki šiol nepasirašytos. Taip vèlgi norima aiškiai pademonstruoti NATO šalims, kad jos rizikuoja priimti ị savo gretas valstybes su neaiškiomis sienomis ir taip įvelti visą Aljansą į teritorinius ginčus;

- karinio tranzito ị Kaliningrado sritį per Lietuvos teritoriją problemos panaudojimą. Šiuo atveju tarp Rusijos ir Lietuvos vèlgi galioja tik laikinas susitarimas, kuris buvo sudarytas 1993 metu pabaigoje po Rusijos kariuomenès išvedimo iš Lietuvos dèl iš Vokietijos išvedamos kariuomenès judejjimo per Lietuvą sąlygų. Net ir išvedus Rusijos kariuomenę iš Vokietijos, Lietuvai nepavyko susitarti su Rusija dèl normalių tranzito sąlygų, todèl kaip kompromisinis sprendimas liko galioti sena laikinoji sutartis. Tuo pačiu Rusija tarsi siekè pademonstruoti, kad šiuo atveju Lietuva nèra valstybė, kuri sugeba spręsti karinio tranzito klausimus ir būtinai ị šias problemas ịvels visą Aljansą.

Be abejonès, šitą sąrašą galima būtų tęsti ir rasti daugiau pavyzdžiu, tarp kurių ypač išsiskiria tarsi netyčiniai Baltijos valstybių teritorijos arba oro erdvès pažeidimai, kuriais tarsi norima pademonstruoti, kad šių valstybių sienų apsauga bus vèl tiktai našta Aljansui.

Taigi Baltijos valstybių ir Rusijos santykiai net ir išvedus Rusijos kariuomenę iš esmès nepasikeitè ir nepagerèjo, nes nè viena pusè net nesiruošẻ keisti visiškai priešingų saugumo politikos pozicijų. Yra visiškai teisus suomių politologas Raimo Väyrynenas, teigiantis, kad

aklavietė, ko gero, yra tiksliausias terminas, apibūdinantis dabartinę Baltijos šalių ir Rusijos santykių būklę; abi pusès mano, kad esminių nuolaidų daryti negalima, o Rusija kaip didesnè valstybė nenori, o galbūt ir negali naudoti jègos, kad būtų pralaužta ši politinè užtvanka ${ }^{19}$.

Žinoma, ši Rusijos ir Baltijos saugumo santykių aklavietė nereiškia, kad šios valstybės daugiau nebendravo tarpusavyje. Tačiau tuo pat metu jų santykiai, nepaisant kariuomenès išvedimo, nebuvo iki galo normalizuoti ir dẻl to kẻlè įtampą visame regione ${ }^{20}$. Dèl to, kad pačios šios konflikto dalyvės negalejo ir, tiesą sakant, netgi nebuvo suinteresuotos daryti nuolaidų ir siekti sutarimo, Baltijos jūros regione susikūrẻ savotiškas ,uždaras nesaugumo ratas“, iš kurio pagrindinès dalyvės jau vien tik

\footnotetext{
19 „Stalemate is perhaps the best way to describe the current Baltic-Russian relationship; both parties considers the major concessions impossible, while Russia as the bigger power is unwilling, and possibly, to use force to break the political logjam“. Väyrynen R., „The Security of the Baltic Countries: Cooperation and Defection" in Knudsen O.F., ed., Stability and the Security in the Baltic Sea Region, London: Franc Cass, 1999, 205

${ }^{20}$ Estijos užsienio reikalų ministerijos interneto svetainèje galima rasti tokị santykių su Rusija ivvertinimą - pagrindinis veiksnys, trukdantis galutinai normalizuoti santykius - tai neužbaigtas tarpvalstybinių sutarčiu bazės formavimas. Pirmiausia trūksta tokių dvišalių susitarimų, kaip sienos sutartis, kaip prekybos, ekonominio bendradarbiavimo sutartis bei sutartis del dvigubo apmokestinimo išvengimo. Žr.: Estonian Ministry of Foreign Affairs, „Estonia and Russia“, http://www.vm.ee/ eng/kat_176/1430.html, (žiūrèta 200206 01). Galima sakyti, kad šis įvertinimas visiškai tinka ir kitoms dviem Baltijos šalims - Latvijai ir Lietuvai.
} 
savo jẻgomis išsikapstyti nebegalëjo. Todèl netgi jų vykdomos politikos priemonès buvo labiau nukreiptos ne į tai, kaip paveikti vienai kitą, bet ị tai, kaip veikti tarptautinę aplinką ir visų pirma pastūmèti NATO viena arba kita linkme. Kitaip tariant, nuo 1995 metų padètis praktiškai nesikeitè. Tik darèsi vis labiau aišku, kad Rusijos ir Baltijos valstybių saugumo dilema gali būti sureguliuota tik platesniame tarptautiniame kontekste ir galbūt sukūrus tokị saugumo režimą, kuris būtų priimtinas abiem konfliktuojančioms pusėms. Tačiau atsižvelgiant ị tai, kad tokio pobūdžio sprendimai gimsta labai lètai, Baltijos jūros regione susikūrè neapibrèžtumo ir laukimo situacija. Šalys tarsi pateko savotišką pereinamajį laikotarpi, kurio pabaigos datos tuomet niekas negalèjo nurodyti.

Taigi demontavus Šaltojo karo laikų palikimą, Baltijos jūros regione susiklostė nauja saugumo dilema, kurios sprendimo alternatyvų paieška ir tapo pagrindiniu politinès darbotvarkés punktu. Nors, tiesą sakant, pagal pagrindinės saugumo problemos pobūdị Baltijos jūros regionas 1995 metais beveik nesiskyrẻ nuo Vidurio Europos regiono, nes Čekijos, Vengrijos ir Lenkijos siekimas stoti ị NATO gali būti paaiškintas tais pačiais motyvais, kaip ir Estijos, Latvijos ir Lietuvos. Atitinkamai ir Rusija neigiamai vertino Vidurio Europos šaliu siekị ir atvirai prieštaravo jam. Bet vis dèlto Baltijos jūros regionui savitumo teikè ne tik Rusijos artumas, bet ir ypatinga Švedijos ir Suomijos laikysena, nes šios šalys ir po Šaltojo karo dabar jau nebe aplinkybių verčiamos, bet savo noru pasirinko kitokią negu Vidurio Europos ir Baltijos valstybės saugumo politikos strategiją. Jos visų pirma nusprendè siekti narystės ne NATO, bet Europos Sajungoje ir dalyvauti jos užsienio ir saugumo politikos formavime. Tuo tarpu Baltijos šalys pirmiausia stojimo paraiškas pateikẻ ne Europos Sajungai, bet NATO.

\subsection{Baltijos valstybiụ saugumo garantijụ alternatyvụ paieška}

Tačiau nepaisant Baltijos šalių nuoseklios oficialios politikos tęsti pasirengimą NATO narystei, netrūko įvairiausių pasiūlymų, idejjų ir svarstymų, kaip kitaip galètų būti sureguliuotas Baltijos šalių saugumo klausimas ir tuo pačiu viso Baltijos jūros regiono saugumo režimas, laikinai arba galbūt net visam laikui Baltijos šalis paliekant už NATO ribų. Šie svarstymai, nors ir neturèjo praktiškai jokio poveikio Baltijos šalių politikai, vis dẻlto buvo pakankamai svarbūs ta prasme, kad jie turẻjo padeti tiek NATO šalims, tiek ir Rusijai apsispręsti, kokios toliau nuostatos laikytis Baltijos šalių atžvilgiu.

Turbūt pagrindinè idejja, kuri buvo tuomet plačiausiai diskutuojama - tai Baltijos jūros regiono saugumo „regionalizacija“, savotiško regioninio saugumo režimo, kurị sudarytų tiktai prie karinių aljansų neprisijungusios (angl. military nonaligned) Baltijos ir Skandinavijos valstybės, sukūrimas. Štai 1996 metų gegužès mènesį buvęs Britanijos užsienio reikalų sekretorius Douglas Herdas pasiūle įsteigti tai, ką jis pavadino „Baltijos saugumo subzoną“21. Iš pirmo žvilgsnio tai atrodè visai logiška idejja, nes Baltijos jūros regionas, kurị sudaro nedidelès demokratiškos ir taikios šalys, gali lengvai suformuoti klasikinị režimą su bendromis normomis, taisyklėmis ir sprendimų prièmimo procedūromis. Iš karto tarsi buvo aišku, kad tokia-

\footnotetext{
${ }^{21}$ Cituojama pagal: Peter van Ham, ,The Baltic States and Europe“ in Hansen B., Heurlin B., eds. The Baltic States in World Politics, New York: St. Martin's Press, 1998, 38.
} 
me regione lengvai prigytų kooperacinio saugumo normos, o ne vienašališkos pastangos, užtikrinti saugumą karinėmis priemonėmis.

Beje, šis pasiūlymas iš karto susilauke paramos Bonoje ir Maskvoje. Šitą pasiūlymą iš dalies paremė net ir Švedija. Tačiau 1996 metų rugpjūčio vizito į JAV metu Švedijos ministras pirmininkas Göranas Perssonas parèmè šią idejją tiktai su išlyga. Ministras pirmininkas pabrèžè, kad nors Švedija ir būtų didžiausia šios grupés dalyvé, bet ji nesiima būti Baltijos valstybių saugumo garantu, nes jos kaip neprisijungusios valstybès statusas neleidžia jai prisiimti kokių nors karinių įsipareigojimų Baltijos šalių atžvilgiu. Todèl, pasak Perssono, pačiu Baltijos šalių vyriausybès labai gerai žino, kad norint subalansuoti galimą Rusijos imperializmo atsikūrimą joms reikia daug didesnès pagalbos negu tai gali pasiūlyti Šiaurès kaimynai.

Tačiau debatų dèl Baltijos jūros regiono saugumo kontekste daugiausia dėmesio susilaukė originalus „,Rand“ korporacijos analitikų Ronaldo Asmuso ir Roberto Nuricko pasiūlymas. Dar 1996 metų vasarą jie rašè, kad Baltijos šalys su pirmaja kandidačių banga greičiausiai į NATO nepateks. Kol bus apsispręsta dèl Baltijos šalių narystės NATO ateityje, Baltijos šalių narystes NATO alternatyva galètų būti kuo skubesnis Estijos prièmimas į Europos Sajungą ir jos padèties sulyginimas su Švedijos ir Suomijos padètimi. Tiesa, šis pasiūlymas buvo pateikiamas tik kaip laikinas sprendimas, ieškant atsakymo ị klausimą, ką būtų galima padaryti po to, kai NATO šalys nepakvies ị Aljansą Baltijos valstybių Madrido susitikime 1997 metų liepą. Studijos autoriai pripažịsta, kad

NATO - ir vien tik NATO - yra pajègi sukurti visuotini saugumo kontekstą, kuriame ir Europos Sajungai būtų lengviau išsiplèsti ị Baltijos šalis, ir NATO nepriklausančioms šalims labiau įsitraukti ị saugumo reikalus ${ }^{22}$.

Pagaliau kalbant apie alternatyvius Baltijos valstybių saugumo užtikrinimo kelius, nereikètų pamiršti, kad ne tik Rusijoje, bet ir Vakaruose buvo žmonių manančių, kad NATO plètimas ị Baltijos valstybes yra neteisinga ir neatsakinga užmačia. Iliustracijos dẻlei galima pateikti, kuo vadovaujasi švedų tyrinètoja Lena Jonson darydama išvadas. Ji tyrinèdama Rusijos politiką NVS šalių atžvilgiu pastebi, kad toje politikoje egzistuoja didelis atotrūkis tarp to, ką deklaruoja ir norètų padaryti Rusija vadinamojo „artimojo užsienio“ šalių atžvilgiu, nes Rusija negali savo tikslų siekimui naudoti karinės jègos. Todėl Rusija išnaudoja naujų valstybių silpnąsias vietas ir stengiasi kištis ị vidinị politinị procesą ir daryti sau naudingą įtaką. Tyrinėtoja mano, kad ši išvada gali būti pritaikyta ir Baltijos valstybių saugumo atvejui. Todèl ir Vakarų atsakas turètų būti atitinkamas:

Baltijos šalių nacionalinio saugumo pažeidumo požiūriu labiausiai tikètina galima Rusijos grèsmè yra politinis spaudimas, o ne karinè galia ir jos grèsmè. Todèl atitinkamai Vakarų atsakas turètų būti nukreiptas ị tai, kad padèti Baltijos šalims minimalizmuoti jų ekonominị ir politini pažeidumą santykiuose su Rusija ${ }^{23}$.

22 „NATO - and only NATO - can create the overall security framework, which will make it easier for the EU to enlarge to the Baltic States and easier for non-NATO countries to become more involved as well“. Asmus R., Nurick R., „NATO Enlargement and the Baltic States“, Survival, Summer 1996, vol. 38, no. 2, 139.

${ }^{23}$ „In terms of the Baltic States' vulnerable national security, the eventual threat from Russia would more likely include the use of political pressure rather then military force or threats. Subsequently, the West answers to this challenge would be help to minimize all economic and political vulnerabilities of the Baltic States in relations to Russia “. Jates in relations to Russia „Jabroad“ in Hansen B., Heurlin B., eds., The Baltic States in World Politics, New York: St. Martin's Press, 1998, 128. 
Logiška Jonson ir kitų panašių samprotavimų išvada būtų tokia, kad iš esmès Baltijos valstybiu saugumo problemai išspręsti tinkama ir adekvati priemonè būtų ne NATO plètimas, bet Baltijos šalių narystė Europos Sajungoje, kuri suteiktų svarbiausią saugumo garantiją - sklandžią šių valstybių socialinę ir ekonomę raidą ir apribotų Rusijos galimybes kreipti tuos procesus sau naudinga linkme.

\subsection{Pirmoji NATO plètros banga ir Rusijos saugumo garantijos}

1997 metais Madrido NATO viršūnių susitikime buvo paskelbta ne perdaug džiugi žinia Baltijos valstybėms - jų prašymų patenkinimas dẻl prièmimo ị NATO atidedamas neapibrěžtai ateičiai. 1997 m. liepos mèn. tiktai Čekija, Vengrija ir Lenkija buvo pakviestos pradèti derybas dèl stojimo ị NATO. Tačiau tai, kas bus labai svarbu ateityje, Madrido viršūnių susitikime taip pat buvo pabrèžta, jog NATO plètra yra procesas, nesibaigiantis šiuo naujų narių prièmimo etapu ir NATO toliau vykdys , atvirų durų" politiką remiantis Šiaurès Atlanto sutarties 10 straipsniu. Todèl Baltijos šalims beliko guostis tiktai tokiu viename sakinyje telpančiu jų pastangų pripažinimu:

Tuo pačiu mes pripažịstame siekiančių narystès Baltijos regiono valstybiụ pažangą, stiprinant stabilumą ir plètojant bendradarbiavimą ${ }^{24}$.

Tolimesnei Baltijos jūros regiono saugumo situacijos raidai pasidarè svarbūs du veiksniai. Pirmiausia tai, kad į NATO buvo pakviesta ne tik Vidurio Europai priklausanti, bet ir Baltijos jūros regionui svarbi valstybè - Lenkija. Lenkijos - Lietuvos siena tapo pirmaja Baltijos valstybių siena su NATO šalimi. Tai buvo ir tam tikra viltis į ateitį, kad NATO plètra nesustos.

Kitas, kaip tuomet atrodė, labai reikšmingas ir Baltijos regionui faktas ịvyko dar iki Madrido deklaracijos paskelbimo. Tai buvo 1997 metų gegužès 27 d. Paryžiuje pasirašytas NATO ir Rusijos Federacijos Steigiamasis tarpusavio santykių, bendradarbiavimo ir saugumo aktas ${ }^{25}$. Akte dar kartą buvo patvirtinta, jog NATO ir Rusija nebelaiko viena kitos priešininkèmis. Pagal ši aktą buvo ịsteigta Nuolatinè jungtinè taryba, kuri turëjo tapti konsultacijų ir bendrų sprendimų, jeigu šalys sutars, forumu. Akte taip pat įvardintos problemos, dèl kurių NATO ir Rusija galètų konsultuotis. Tai konfliktų prevencija, masinio naikinimo ginklų platinimas, informacijos saugumo ir gynybos klausimai, mainai, gynybos pramonès konversija, aplinkos sauga, civilinė sauga ir kt. NATO ir Rusijos Akte taip pat pažymèta, kad pasirašiusi šį dokumentą, NATO netampa pavaldžia jokiai kitai organizacijai ar valstybei ir neketina keisti savo įsipareigojimų saugumo srityje dabartiniams ir būsimiems NATO nariams. Akte taip pat nebuvo jokiu garantijų Rusijai, kad NATO ir toliau nebus plečiama.

Tokio pobūdžio NATO ir Rusijos santykius reglamentuojantis dokumentas, be abejonès, buvo naujas reiškinys. Dokumentas pirmą kartą tarsi pademonstravo, kad egzistuoja tam tikri principai, normos ir taisyklès, po kuriomis gali savo parašus palikti ir buvę Šaltojo karo priešininkai. Tai buvo žingsnis ị priekị, lyginant su ribotu

\footnotetext{
${ }^{24}$ „At the same time, we recognise the progress achieved towards greater stability and cooperation by the states in the Baltic region which are also aspiring members." NATO Summit. Madrid, July 89, 1997, Madrid Declaration on Euro-Atlantic Security and Cooperation, http://www.nato.int/ docu/pr/1997/p97-081e.htm, (žiūrèta 200206 01).

${ }^{25}$ NATO - Russian Summit, Founding Act on Mutual Relations, Cooperation and Security between NATO and the Russian Federation, May 27, 1997, http://www.nato.int/docu/basictxt/fndact-a.htm, (žiūrèta 20020601 ).
} 
NATO ir Rusijos susitarimu PfP. Tačiau, iš kitos pusès, vis dẻlto buvo akivaizdu, kad šiam dokumentui tarsi trūksta kažkokios grandies, kuri tampriau jungtų kol kas labiau oponuojančias negu bendradarbiaujančias jègas. Taip, matyt, buvo todèl, kad kiekviena pusè vis dèlto skirtingai įsivaizdavo šio Akto reikšmę ir puoselèjo skirtingus lūkesčius. NATO valstybès, kurdamos tokią Nuolatinę tarybą, tikèjosi sušvelninti neigiamą Rusijos reakciją, kurios buvo tikimasi po liepos mėnesį numatomo paskelbimo, kad už dviejų metų į NATO bus priimtos Lenkija, Čekija ir Vengrija. Tuo tarpu Rusija, matyt, tikèjosi, kad turès didesnę ịtaką NATO sprendimams ir galès sustabdyti tolesnę NATO plètrą visų pirma būtent ị Baltijos jūros regioną po to, kai ị ją bus priimtos Lenkija, Čekija ir Vengrija. Rusija, matyt, buvo linkusi traktuoti šio Akto pasirašymą ir NATO sprendimą gana ribotai plèsti Aljansą savo diplomatijos laiméjimu ir dabar, matyt, nusprendè, kad atèjo laikas jai pačiai perimti iniciatyvą bei pradèti vykdyti aktyvesnę politiką Baltijos jūros regione.

Ryškiausias tokios pasikeitusios Rusijos politikos, savotiško détente apraiška buvo Rusijos sprendimas vis dèlto 1997 metais pasirašyti Lietuvos ir Rusijos tarpvalstybinès sienos sutartị ir šiame kontekste pasiūlyti Lietuvai ir kitoms Baltijos šalims sudaryti saugumo garantijų sutartị. 1997 metų rugsẻjo 22 d. Rusijos užsienio reikalų ministras Jevgenijus Primakovas (kuris pakeitė Andrejų Kozyrevą 1996 metais), kalbẻdamas Jungtinių Tautų Generalinėje Asamblëjoje, jau oficialiai pareiškė, kad Rusija yra suinteresuota Baltijos šalių stabilumu ir norètų užtikrinti jų saugumą. Pasak Primakovo, Rusija galètų i̦sipareigoti garantuoti Baltijos šalių saugumą, abiem pusėms pasirašius gerų kaimyninių santykių sutartis. Ministro manymu, tokios sutartys galètų išaugti į regioninio saugumo paktą. Tokị pat pareiškimą išgirdo ir Lietuvos prezidentas Algirdas Brazauskas oficialaus vizito Maskvoje metu spalio ménesį. Jelcinas garantavo, kad Lietuvos nelaukia jokie netikètumai iš Rusijos.

Kaip ir buvo galima prognozuoti, Rusijos iniciatyva buvo tiek Lietuvos, tiek ir kitų dviejų Baltijos valstybių atmesta. „Nei vienašalès saugumo garantijos, įteisintos tarptautiniu susitarimu, nei regioniniai saugumo paktai negali užtikrinti Europos, kaip ir Lietuvos, saugumo. Lietuvos požiūriu saugumo ir stabilumo erdvę Europoje išplès Baltijos valstybių integracija ị Europos Sajungą bei NATO“26 - tvirtinama Lietuvos užsienio reikalų ministerijos dokumente.

Kodèl iš pirmo žvilgsnio toks patrauklus pasiūlymas buvo atmestas? Turbūt geresnio paaiškinimo už tą, kurị yra pateikęs dar 1991 metais Zbigniewas Brzezinskis savo knygoje „The Grand Chessboard“vargu ar įmanoma rasti:

[...] Rusų demokratai paprasčiausiai nepajègė suprasti nei Vidurio Europos gyventojų pasipiktinimo daugiau kaip puse šimtmečio trukusiu Maskvos dominavimu, nei jų noro tapti platesne euroatlantinès sistemos dalimi ${ }^{27}$.

${ }^{26}$ ELTA, „Rusijos garantijos negali užtikrinti Lietuvos saugumo“, 1997 m. spalio 30 d.

$27,[\ldots]$ the Russian Democrats simply could not grasp the depth either of the Central European's ressentment over half a century of Moscow domination or of their desire to be part of a larger EuroAtlantic system. " Brzezinsky Z., The Grand Chessboard. American Primacy and Its Geostrategic Imperatives, New York: BasicBooks, 1997, 102. 
Taigi Rusijos ir Baltijos valstybių détente buvo gana trumpas. Ir tolesnio progreso santykiuose nebevyko. Pagaliau ir NATO - Rusijos Nuolatinè jungtinè taryba pasirode visiškai neveiksni, kol galutinai jos darbas nutrūko 1999 metais dẻl Rusijos protesto prieš NATO veiksmus, bandant karine jėga spręsti Kosovo krizę.

\subsection{Laikinas Baltijos klausimo „sureguliavimas“}

Po NATO sprendimo plèstis, Europoje susikloste nauja situacija ir pradëjo ryškèti naujos saugumo sistemos kontūrai, kuriuose galëjo atsirasti vietos ir Baltijos valstybẻms. Todèl, kaip nebūtų paradoksalu, bet, ko gero, lengviausiai prie besikeičiančios situacijos savo politiką pritaikyti buvo būtent Baltijos šalims. Joms iš esmès nieko nereikẻjo keisti, bet tik toliau tęsti pradètus darbus PfP ir Euroatlantinès partnerystės taryboje. Negavusios pakvietimo į NATO Baltijos valstybès turèjo pasitenkinti ir iš tikruju pasitenkino bei gerai išnaudojo savo, kaip beveik visuotinai pripažintų šalių kandidačių i NATO, padètį. Jos suprato, kad NATO iš tiesų yra sunku itraukti šias šalis į Aljansą jau pirmame plètros etape. Bet pirmasis sẻkmingas NATO išsiplètimas buvo rimta paraiška galutinai išspręsti saugumo problemas regione taip, kaip to pageidavo būtent Baltijos valstybės.

Visos Baltijos šalys po „pirmojo atmetimo“ stengèsi bent iš dalies kompensuoti nepasiektą narystę, aktyviai ir kiek ịmanoma daugiau dalyvaudamos PfP ir tuo pačiu sieké pademonstruoti, kad jos nèra vien tiktai saugumo „vartotojos“, bet gali būti naudingos visam Aljansui. Baltijos šalių taikdariai dalyvavo misijose Bosnijoje, kurią, vadovaujant JAV ir NATO, vykdẻ drauge su švedais, suomiais, lenkais ir netgi rusais. Baltijos šalys taip pat aktyviai dalyvavo PfP metiniuose kariniuose mokymuose „Baltic Challenge". Visos trys šalys taip pat dalyvavo PfP vykdomame Planavimo ir peržiūros procese, kuriuo buvo siekiama plètoti šalių partnerių ir aljansų karinių pajègų sąveikumą ir atvirumą. Siekimas tvirtinti ryšius su NATO ir galiausiai ịstoti į Aljansą pozityviai pasitarnavo ir pačių Baltijos šalių tarpusavio bendradarbiavimui saugumo ir gynybos srityse (pvz., Baltbat, Baltdeflcol) bei spartino jų gynybos politikos atsinaujinimą.

Tuo tarpu JAV, atsižvelgdama į Baltijos šalių problemos aštrumą ir siekdama savotiškai pademonstruoti, kad durys ị NATO lieka atviros, inicijavo ir 1998 metu sausio mėnesį pasiraše su Baltijos valstybėmis JAV ir Baltijos šalių Partnerystės chartiją. Šis dokumentas Baltijos valstybėms ir jų saugumui buvo svarbus visų pirma dèl to, kad turbūt pirmą aukščiausiame politiniame lygmenyje, JAV prezidento parašu buvo patvirtinta, kad i jų norą stoti į NATO žiūrima pakankamai rimtai. Nors Chartija nesuteike jokių ypatingų saugumo bei būsimos narystès NATO garantijų iš JAV pusès, vis dẻlto joje deklaruojama, kad pagrindinis dokumento signatarų tikslas yra Baltijos šalių inkorporacija ị Europos ir transatlantines politines, ekonomines saugumo ir gynybos institucijas ${ }^{28}$. Nors Baltijos chartija tiesiogiai negarantavo, kad Baltijos respublikos bus priimtos į NATO, bet JAV administracija paliko mažai abejoniǔ dèl savo ịsipareigojimo padèti kurti sąlygas, kad šios šalys įstotų į NATO ateityje. Ši JAV administracijos pozicija buvo patvirtinta per Chartijos pasirašymo ceremoniją, kuomet prezidentas Billas Clintonas pareiške, jog Amerika yra apsisprendusi kurti sąlygas, kurios vieną dieną atvertų NATO duris Estijai, Latvijai ir Lietuvai.

${ }^{28}$ A Charter of Partnership Among the United States of America and the Republic of Estonia, Republic of Latvia, and Republic of Lithuania, Washington, DC, January 16, 1998. http:// www.usemb.se/BalticSec/baltic_charter.html, (žiūrèta 200206 01). 
1995-2000 metai - tai laikotarpis, kada iš esmès vyko debatai ir buvo rengiamasi sprendimui, kuris iš dviejų pagrindinių Baltijos jūros saugumo režimo variantų yra tinkamesnis ir atitinkamai vertas didesnès politinès paramos. Vienas ir pagrindinis siūlomas variantas, kuris, nepaisant viso patrauklumo, atrodè vis dèlto pakankamai nerealus - tai nuosekli NATO plètra ir galutinis Baltijos regiono ịjungimas ir euroatlantinę saugumo zoną. Kaip alternatyva šiam projektui vienaip arba kitaip buvo keliama ir Baltijos jūros regiono saugumo „regionalizacijos“ ideja. Ypač šie svarstymai suintensyvejo, kai buvo nutarta Baltijos šalių i pirmają NATO plètros bangą neįtraukti. Tačiau šis specifinis saugumo režimas, pagristas specialia regionine sutartimi arba regioniniu saugumo paktu, pasirodè nesąs priimtinas nė vienai Baltijos jūros valstybei, išskyrus Rusiją. Dar būtų galima paminèti ir Europos Sajungos inicijuotus debatus bei kai kuriuos veiksmus, pradedant formuoti Europos Sajungos saugumo ir gynybos politiką (ESGP). Tačiau, tiesą sakant, šios iniciatyvos pavadinimas yra kiek klaidinantis, nes ši gynybos politika neturi nieko bendro su gynyba ir negali būti alternatyva NATO, kuri būdama kolektyvinès gynybos organizacija, gali imtis ir krizių valdymo operacijų. Tuo tarpu ESGP apima tiktai vadinamąsias „Petersbergo užduotis“. Baltijos valstybės atitinkamai remdamos Europos Sajungos iniciatyvą ir pareiškẻ savo pasirengimą įnešti ir savo indèlį, tačiau tas indèlis būtų tos pačios pajègos ir resursai, kurie yra skirti NATO operacijoms remti.

Taigi per nagrinètą laikotarpị esminio persilaužimo, sprendžiant klausimą, koks turètų būti saugumas Baltijos jūros regione taip ir nepavyko pasiekti. Liko tokia neapibrèžtumo situacija. Viena vertus, Baltijos valstybėms niekada nebuvo pasakyta, kad ateityje jos nebus priimtos ị NATO. Priešingai, jos tarsi tapo kone oficialiomis šalimis kandidatemis įstoti ị šią organizaciją. Čia principinę reikšmę turejo paties NATO Strateginès koncepcijos evoliucija, užfiksuota 1999 metų balandžio mėnesio NATO valstybių lyderių susitikime Vašingtone.

Antra vertus, vis dẻlto šių šalių NATO narystès perspektyva taip ir liko pakankamai miglota, nes dinamiškai besikeičianti tarptautine padètis, NATO ir Rusijos Nuolatinès jungtinès tarybos neveiklumas, Kosovo krizè gerokai aštrino Rusijos ir NATO santykius ir dèl to greitą ir plačią NATO plètrą, kurioje galbūt atsirastų vietos ir Baltijos valstybėms, kartais dare netgi labai abejotina. Vis dèlto, bent jau formaliai žiūrint, besiformuojančiam Baltijos jūros regionui buvo ypatingai svarbus 1997 metu NATO ir Rusijos susitarimas. Pats faktas, kad NATO ir Rusija vis dèlto pabandè kurti naują tarpusavio santykių režimą, buvo labai svarbus. Sukurtą infrastruktūrą sutrukdè išnaudoti tiktai politinès valios trūkumas. Tačiau, kaip paaiškèjo vèliau, kartais gali susiklostyti situacijos, kada politinè valia gali gana greitai pasikeisti.

\section{2001 metai: atrasta trūkstama grandis?}

1999-2000 metais diskusijos dèl Europos saugumo architektūros ir NATO plètros tarsi atslūgo, nes tapo aišku, kad principiniams sprendimams metas dar neatejo. Dviejose svarbiausiose proceso valstybèse - JAV ir Rusijoje - atejo laikas valdžios pasikeitimams. JAV prezidento Clintono antroji kadencija jau ejjo ị pabaigą ir JAV prasidèjo priešrinkiminè kampanija. Tuo tarpu Rusiją krète prezidento Jelcino inicijuojami vyriausybės vadovų pasikeitimai. 1999 metais Rusijos Vyriausybė vèl atnaujino karą Čečènijoje, galiausiai ir pats Jelcinas 2000 metų išvakarèse netikètai, 
kaip jam ịprasta, pareiškẻ apie savo atsistatydinimą. Todèl 2000 kovo mėnesį turèjo ivykti ir Rusijos prezidento rinkimai.

Tačiau pasibaigus valdžių pasikeitimo procesams JAV ir Rusijoje, neatrode, kad tarptautinèje situacijoje įvyks teigiamų permainų. Netgi priešingai. Kartais atrodé, kad naujasis Rusijos prezidentas, Vladimiras Putinas, yra linkęs sugriežtinti savo opozicinę laikyseną Vakaru atžvilgiu ir netgi bando telkti priešišku JAV valstybių bloką. Putinas, jau tapęs prezidentu, aplankẻ Kiniją, Kubą ir netgi Siaurès Korëją. Akivaizdžiai sustiprejo ir autoritarinès tendencijos pačios Rusijos viduje. Tuo tarpu JAV, šiaip taip po sudètingos balsų perskaičiavimo procedūros, išrinkus prezidentu George'ą W. Bushą ir jam perėmus vadovavimą JAV užsienio politikai, atrodo paaštrèjo prieštaravimai tarp JAV ir jų sajungininkių Vakarų Europoje. Vakarų Europos didžiujų valstybių vyriausybės gana skeptiškai žiūrejjo ị JAV iniciatyvą pradèti kurti nacionalinės priešraketinès gynybos sistemą bei pareiškimus, kad JAV gali pasitraukti iš Balkanų.

Štai tada NATO plètros ateities klausimas buvo tarsi atsidūręs antrame plane. Kadangi principinių sprendimų buvo laukiama tiktai 2002 metų lapkritį, tai neapibrèžta situacija gimdè įvairiausius plètros scenarijus ir spekuliacijas. Vieni sakè, kad jeigu šitame santykių neapibrèžtumo su Rusija ir nesutarimų su Vakarų Europa kontekste NATO ir plésis, tai plèsis tik labai ribotai - bus priimtos tik gynybine strategine prasme svarbios šalys - Slovenija ir Slovakija. Tuo tarpu Baltijos valstybių atžvilgiu įvairūs komentarai būdavo ypač atsargūs. Buvo visai rimtai svarstomi netgi tokie variantai, kad gali būti pakartotas jau 1997 metais Europos Sajungos pasirinktas scenarijus. Kaip žinia, tuomet deryboms dèl narystės ES nusprendè pakviesti tik vieną Baltijos valstybę - Estiją. Dabar galima būtų šią patirtị pritaikyti ir NATO plètrai, 2002 metais pakviečiant į NATO Sloveniją, Slovakiją, vieną Baltijos valstybę - Lietuvą, kurioje yra santykinai nedidele rusų mažuma ir kuri jau turi sieną su NATO valstybe - Lenkija. Tokiu atveju būtų galima tikètis taip iki galo nesupriešinti Rusijos, bet tuo pačiu parodyti jai, kad NATO, nors ir iš lèto, bet vis dèlto pagal planą juda pirmyn ${ }^{29}$.

Tačiau visoms šioms spekuliacijoms užkirto kelią pirmą kartą naujosios JAV administracijos viešai pareikšta pozicija NATO plètros atžvilgiu. Gerų naujienų Baltijos valstybès, o taip ir kitos šalys, norinčios tapti NATO narėmis, iš JAV prezidento Busho išgirdo 2001 metų birželio mėnesị, jo vizito Lenkijoje metu. Susitikime su Varšuvos universiteto déstytojais ir studentais JAV prezidentas pareiškė:

Aš tikiu, kad NATO narèmis taps visos Europos demokratijos, kurios to siekia ir kurios yra pasirengusios prisiimti dali NATO atsakomybės. Tiktai klausimas „kada?“, o ne klausimas „,ar?“ turi dabar būti svarstomas NATO. Kadangi mes planuojame NATO plètrą, jokia valstybẻ negali tapti kitų valstybių interesų įkaite. Mes nežaisime laisvų Europos tautų likimu. Daugiau jokių Miunchenų. Daugiau jokių Jaltų. Pasakykime tiems, kurie kovojo už demokratiją ir laisvą rinką, tai, ką mes jau pasakème lenkams: nuo šiol, tai ką jūs sukūrẻte, bus visada jūsų. Niekas negali atimti jūsų laisvès ir jūsų šalies.

Kitais metais NATO lyderiai susitiks Prahoje. Jungtinès Valstijos ir jos sajungininkai bus pasiruošę priimti istorinius sprendimus dèl NATO plètros. Lenkija ir Amerika

\footnotetext{
${ }^{29}$ Gordon P., Steinberg J.B., „NATO Enlargement: Moving Forward; Expanding the Alliance and Completing Europe's Integration“, The Brookings Institution Policy Brief, n. 90, November 2001, http://www.brook.edu/comm/policybriefs/pb90.htm, (žiūrèta 200206 01).
} 
puoselèja tą pačią viziją. Planuodami Prahos susitikimą, mes neturètume skaičiuoti, kaip lengviau išsisukti, bet kiek mes galime pastūmèti laisvès reikalą.

NATO plètra išpildys NATO pažadą. Ir šis pažadas šiandien mus veda ị Rytus ir ị Pietus, ị Šiaurę ir pirmyn ${ }^{30}$.

Kaip galime matyti, Busho pareiškimas buvo pakankamai aiškus ir griežtas, bet tuomet dar ne daug kas atkreipe dèmesị i tai, kad Rusijos reakcija ị ši pareiškimą buvo kaip niekada labai santūri ir rami. Vèliau, 2001 metų vasarą, Putinas žengè dar vieną žingsnị, pripažįstant NATO plètros neišvengiamumą, jis pareiškẻ, kad ir pati Rusija gali panorèti tapti Aljanso nare. Kaip paaiškẻjo vėliau, tai buvo ne atsitiktinumas, bet jau pradejusios keistis Rusijos užsienio politikos išraiška. Tiesą sakant, tokio pasikeitimo požymių buvo ir daugiau. Jau nuo pat 2000 metų pradžios, nors ir siųsdamas prieštaringus signalus dèl Rusijos galimos provakarietiškos orientacijos, naujai išrinktas Rusijos prezidentas kūrẻ konstruktyvesnio bendradarbiavimo prielaidas. 2000 metų gegužès ménesị vèl atnaujino darbą NATO ir Rusijos Nuolatinè jungtinė taryba, kurios veikla buvo suspenduota dẻl Rusijos protesto prieš NATO karinę kampaniją Kosove. Netrukus, 2001 m. vasario mėnesi, Maskvoje pradëjo veikti NATO informacijos biuras. Aišku, galutinis lūžis įvyko 2001 metų rugsèjo 11 d. Aiškiai ir vienareikšmiškai pareikšta Putino pozicija pasibaisėtinų teroro aktų Niujorke ir Vašingtone atžvilgiu, liudijo, kad pagaliau JAV ir Rusija gali suartėti. Kitaip tariant, atsirado trūkstama grandis - „bendras priešas“, su kuriuo ir norejo, ir turèjo kovoti abi pusès.

Šias permainas Baltijos jūros regionui, ko gero, geriausiai charakterizavo britų savaitraštis „Economist“, kuriame buvo apžvelgiami naujausi Rusijos ir NATO santykių pokyčiai, ypač atsižvelgiant į numatomą NATO plètrą ir galimą Baltijos valstybių narystę Aljanse, kuri, pasak leidinio, dar prieš penkerius metus atrodè neịmanoma. Tuo tarpu dabar Baltijos valstybès tikrai gali tikètis pakvietimo ị NATO, nes Rusija, taip iš esmès pasikeitus tarptautinei politinei situacijai ir iškilus naujoms grèsmėms, nustoja būti tokia nesukalbama ir nebemato prasmès taip aršiai prieštarauti Baltijos šalių prièmimui, ir netgi gali leisti sau sakyti, kad NATO plètra yra nebeaktuali Rusijos saugumui. Dar daugiau, Putinas igijo galimybę savo šalies vidaus opozicijai ir Rusijos generolams paaiškinti, kad NATO iš viso nebetenka karinès reikšmės, nes, kaip parode karinė kampanija Afganistane, kovai su terorizmu NATO yra mažai naudinga - svarbiausius sprendimus JAV priima vienašališkai ir pačios pasirenka sau partnerius konkrečioms operacijoms ${ }^{31}$.

\footnotetext{
${ }^{30}$ „I believe in NATO membership for all of Europe's democracies that seek it and are ready to share the responsibilities that NATO brings. The question of „when“ may still be up for debate within NATO; the question of ,whether" should not be. As we plan to enlarge NATO, no nation should be used as a pawn in the agendas of others. We will not trade away the fate of free European peoples. No more Munichs. No more Yaltas. Let us tell all those who have struggled to build democracy and free markets what we have told the Poles: from now on, what you build, you keep. No one can take away your freedom or your country.

Next year, NATO's leaders will meet in Prague. The United States will be prepared to make concrete, historic decisions with its allies to advance NATO enlargement. Poland and America share a vision. As we plan the Prague Summit, we should not calculate how little we can get away with, but how much we can do to advance the cause of freedom.

The expansion of NATO has fulfilled NATO's promise. And that promise now leads eastward and southward, northward and onward“. Bush G.W., Remarks by the President in Address to Faculty and Students of Warsaw University, http:/www.whitehouse.gov/news/releases/2001/06/ 20010615-1.html, (Žiūrèta 20020601 ).

31 „Putin's unscrambled eggs: Russia, NATO and even the Baltic states may end up friends“, Economist, March 9, 2002.
} 
Taigi jau 2002 metų pradžioje tapo aišku, kad iš esmès NATO plètimo ị Baltijos jūros regioną klausimas yra išspręstas. Tačiau galutinis saugumo režimo regione pavidalas priklauso nuo to, kokius konkrečius teisinius ir institucinius rezultatus atneš Rusijos ir NATO suartejjimas. Tai iš dalies paaiškejjo 2002 metu gegužès mènesi Reikjavike per NATO valstybių ir Rusijos užsienio reikalų ministrų susitikimą, kada buvo galutinai suderintas susitarimas dèl glaudesnio NATO šalių ir Rusijos bendradarbiavimo. Pats dokumentas „NATO-Rusijos santykiai: Nauja kokybe்“"32, kuriuo formaliai buvo įsteigta nauja NATO ir Rusijos Taryba, buvo pasirašytas 2002 metų gegužès 28 d. Romoje NATO ir Rusijos viršūnių susitikime.

Formaliai ir oficialiai žiūrint, šis dokumentas turètų leisti suaktyvinti ir sustiprinti kovą su pagrindine XXI amžiaus grèsme - tarptautiniu terorizmu. Svarbiausias šio dokumento skirtumas nuo 1997 metų NATO ir Rusijos steigiamojo tarpusavio santykių, bendradarbiavimo ir saugumo akto yra tas susitarimo punktas, pagal kurị Rusija dalyvaus priimant NATO sprendimus. Iki tol NATO šalys iš pradžių priimdavo sprendimą, o paskui supažindindavo su juo Rusiją. Tai labiausiai ir kèle Rusijos nepasitenkinimą. Dabar numatoma su Rusija tartis iš karto. Tam reikalui steigiama nauja Taryba, kuriai tiesiogiai vadovaus NATO generalinis sekretorius. Bet ir ši Taryba svarstys ne visus saugumo klausimus. Čia, kaip ir pagal 1997 metu aktą, bus tariamasi dėl bendradarbiavimo, kovojant su terorizmu, o taip pat dèl nusiginklavimo ir bendrų veiksmų stichinių nelaimių atveju. Tarybos veikla padės formuoti bendrą požiūrị į tai, kaip užkirsti kelią masinio naikinimo ginklų platinimui, bendrai veikti, kuriant priešraketinės gynybos sistemą, vykdyti taikos palaikymo operacijas ir t.t. Tačiau tuo pat metu dokumentas nesuteikia Rusijai veto teisès sprendžiant kitus NATO darbotvarkès bei plètros klausimus ${ }^{33}$. Taip pat NATO neatsisako ir kone pačios pagrindinès Šiaurès Atlanto sutarties nuostatos, kuri numato, kad kurios nors Aljanso šalies užpuolimas yra viso Aljanso užpuolimas. Todẻl nutikus tokiam atvejui, NATO neprivalo klausti Rusijos, ar jai galima pulti agresoriu.

Žinoma, šiandien sunku pasakyti, kaip ir ką konkrečiai veiks ši naujoji NATO_Rusijos Taryba ir ar neištiks jos ankstesnès Nuolatinès jungtinès likimas. Pasak „Radio Liberty" komentatorių, ir ankstesnis formatas sudarè visas prielaidas bendradarbiavimui, bet problemos kilo dèl to, kad Rusija nerodè politinès valios tokiam bendradarbiavimui. Dabar yra pagrindo manyti, kad tokia politinè valia bus ir Romos deklaracijoje, kur daugeliu klausimų Rusija bus lygiateisè su kitais NATO nariais ${ }^{34}$.

Pagaliau, jeigu NATO ir Rusijos Taryba realiai veiks, tuomet ir Baltijos jūros regiono valstybès, kurios įstos į NATO, irgi taps šios Tarybos naremis. Taip ir jų saugumo santykiai su Rusija turètų igyti naują kokybę, kurią ir būtų galima pavadinti naujojo saugumo režimo Baltijos jūros regione ịsikūnijimu. Šiaip ar taip, pagrindinès konfliktinès linijos Baltijos jūros regione dalyvės - Rusija ir Baltijos valstybės - pagaliau bendrautų platesniame tarptautiniame kontekste, kuris sudarytų prielaidas ir galutiniam jų tarpusavio santykių normalizavimui ir galbūt leistų galutinai užbaigti jų tarpusavio Šaltajị karą.

\footnotetext{
32 Rome Summit - 28 May 2002, NATO-Russia Relations: A New Quality. Declaration by Heads of State and Government of NATO Member States and the Russian Federation, http://www.nato.int/ docu/basictxt/b020528e.htm, (žiūrèta 200206 19).

${ }^{33}$ Fact Sheet „NATO-Russia Council“, http://www.whitehouse.gov/news/releases/2002/05/20020528 3.html, (žiūrèta 20020601 ).

${ }^{34}$ Радио Свобода „Новые отношения России и НАТО“, http://www.svoboda.org/archive/ 11_world/0502/11.051602-1.asp, (žiūrèta 200206 19).
} 


\section{Išvados}

Apibendrinant atlikto tyrimo rezultatus, Baltijos jūros regiono saugumo režimo kaitą būtų galima supaprastintai pateikti taip:

\section{Baltijos jūros saugumo režimo kaita}

\begin{tabular}{|c|c|c|}
\hline Laikotarpis & Pagrindiniai iššūkiai & $\begin{array}{l}\text { Tarptautinès teisès aktai, kuriuose } \\
\text { užfiksuoti regiono saugumui svarbūs } \\
\text { principai, normos ir taisyklès }\end{array}$ \\
\hline iki 1991 & $\begin{array}{ll}\text { - } & \text { Šaltasis karas; } \\
\text { - } & \text { Šiaurés balansas. }\end{array}$ & $\begin{array}{ll}\text { - } & \text { Jungtiniu Tautu chartija; } \\
\text { - } & \text { Suomijos ir Sovietų Sajungos } \\
\text { draugystés, bendradarbiavimo ir } \\
\text { abipusćs pagalbos sutartis; } \\
\text { - } \quad \text { ESBK: Helsinkio baigiamasis } \\
\text { Aktas. }\end{array}$ \\
\hline 1991-1994 & $\begin{array}{l}\text { - } \begin{array}{l}\text { Senojo saugumo režimo } \\
\text { demontavimas; }\end{array} \\
\text { - } \quad \text { Rusijos kariuomenćs išvedimas iš } \\
\text { Baltijos valstybių. }\end{array}$ & $\begin{array}{l}\text { - } \quad \text { ESBK: Naujosios Europos } \\
\text { Paryžiaus chartija; } \\
\text { - } \quad \text { Siaurés Atlanto bendradarbiavimo } \\
\text { taryba; } \\
\text { - } \quad \text { Taikos partnerystc்: kvietimas ir } \\
\text { réminis dokumentas. }\end{array}$ \\
\hline $1995-2001$ & $\begin{array}{ll}\text { - } & \text { Rusijos ir Baltijos valstybių Šaltasis } \\
\text { karas; } \\
\text { - } & \text { Pirmasis NATO plètimas; } \\
\text { - } & \text { Baltijos valstybių saugumo } \\
\text { problemos sprendimo alternatyvu } \\
\text { paieška ir saugumo } \\
\text { „regionalizacijos“ pasiūlymo } \\
\text { atmetimas. }\end{array}$ & 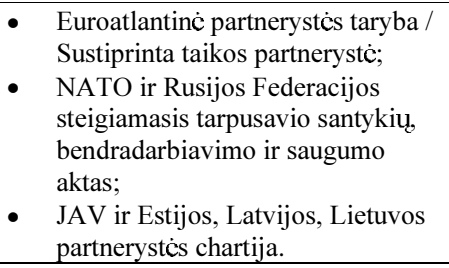 \\
\hline nuo 2002 & $\begin{array}{ll}\text { - } & \text { Kova su terorizmu - naujas } \\
\text { pagrindas NATO ir Rusijos } \\
\text { suartéjimui; } \\
\text { - Baltijos valstybių pricmimas i } \\
\text { NATO. }\end{array}$ & $\begin{array}{ll}\text { - } & \text { Romos deklaracija „NATO ir } \\
\text { Rusijos santykiai: nauja kokybéc; } \\
\text { - } \quad \text { Siaurés Atlanto sutartis ir Aljanso } \\
\text { strateginé koncepcija. }\end{array}$ \\
\hline
\end{tabular}

Kaip iš viso tyrimo, taip ir iš čia pateiktos lentelès galima aiškiai matyti, kad saugumo klausimuose (čia turiu omenyje visų pirmą „griežtajị “ (angl. hard) saugumą) vien tik Baltijos jūros valstybes apimančios institucijos ir netgi Europos Sajunga praktiškai neturi realios reikšmès. Bandymai iškelti Estijos, Latvijos ir Lietuvos saugumo klausimus Baltijos jūros valstybių taryboje, o taip netgi pati regioninio saugumo pakto idejja buvo iš karto ir be didesnių diskusijų atmesti, kaip neadekvatūs problemos mastui. Nors Baltijos jūros regionas atrodo lyg ideali vieta, kur būtų galima suformuoti klasikinį pilnavertị regioninị saugumo režimą su bendromis normomis, taisyklemis ir sprendimų prièmimo procedūromis, ši prielaida iš esmés pasirodo esanti klaidinga tik dẻl vienos paprastos priežasties - ic ši regioną niekaip negali îsitekti Rusija, nors šiandien ji jau ir nebe Sovietų Sajunga.

Regioninis saugumo režimas Baltijos jūros regione su visomis pakrantès valstybėmis, įskaitant ir Rusiją, negalètų sẻkmingai gyvuoti, nes ši valstybė aiškiai išsiskirtų ir dominuotų. Bet šis režimas tuo labiau negalètų gyvuoti be Rusijos, nes 
būtent su šia šalimi yra susijusi pagrindinè konfliktinè linija ir pagrindinis saugumo iššūkis šiame regione. Todèl tiktai platesnio masto tarptautinès institucijos yra pajègios spręsti Baltijos saugumo dilemą ir vykdyti konfliktų prevencijos funkciją.

Galëjome įsitikinti, kad 1991-1994 metais su šia užduotimi sèkmingai susidorojo ESBK. ESBK buvo ta tarptautinè sąlyga, kuri užtikrino sèkmingą Rusijos kariuomenès išvedimą iš Baltijos valstybių. Tačiau, netrukus tapo aišku, kad ESBK mažai kuo gali pagelbėti toliau galutinai reguliuojant ir normalizuojant Baltijos valstybių ir Rusijos tarpusavio santykius. Kaip žinia, išvedus Rusijos kariuomenę konfliktas, igavo kitokị pavidalą - regione iš esmès tarp Baltijos valstybių ir Rusijos prasidèjo miniatiūinis Šaltasis karas su savo paaštrèjimo ir détente laikotarpiais. Tuo tarpu ESBK beveik nieko negalèjo imtis, kad tas karas pasibaigtų. Ji tik geriausiu atveju galëjo užkonservuoti status quo, bet negalëjo būti pakankamu veiksniu, padedančiu sureguliuoti saugumo problemas. Todèl šitą regioninị Saltajį karą galejjo užbaigti tiktai tokios tarptautinès institucijos, kurios yra pajėgios su Rusija bendrauti kaip lygios su lygia. Tokia institucija ir tapo NATO. Iš pradžių sujungusi savo buvusias priešininkes į NACC, po to į EAPC bei PfP programas. NATO sugebejo surasti ir dar ypatingą santykių institucionalizacijos su Rusijos formą - Nuolatinę jungtinę tarybą, kuri pradèjo savo veiklą drauge su sprendimu pradèti plèsti Aljansą, priimant tris Vidurio Europos šalis. Taigi Baltijos jūros regione per praejusị dešimtmetị vis labiau stiprèjo ir vis labiau buvo matomas stabilizuojantis NATO vaidmuo. Tačiau tenka konstatuoti, kad ir jis nebuvo pakankamas veiksnys, sąlygojęs galutinę Rusijos ir Baltijos valstybių santykių normalizaciją. Todèl praktiškai iki pat 2002 metų Baltijos jūros regione egzistavusį saugumo režimą galima būti apibūdinti, kaip užkonservuotą neapibréžtumo situaciją, kurios sprendimas buvo nuolat atidèliojamas ateičiai.

Pagaliau 2002 metų lapkritị, kada rašomos paskutinės šio darbo eilutès, NATO Prahos viršūnès jau paskelbẻ apie savo apsisprendimą priimti į savo gretas Baltijos valstybes. Todèl, galima sakyti, kad iš esmès saugumo režimo Baltijos jūros regione formavimasis tikrai pereina į naują kokybinį lygị. Jis tampa dar labiau NATOcentrišku režimu negu iki šiol, nes netgi tos šalys, kurios formaliai nebus NATO narès, vis tiek bus užmezgusios solidžius ryšius su šia organizacija. Tai jau seniai galioja Suomijos ir Švedijos atžvilgiu. Bet dabar yra šansas, kad tą patị bus galima pasakyti ir apie Rusiją, kurios partnerystès santykiai su NATO jau įtvirtinti 2002 metų gegužès 28 d. Romos deklaracijoje. Taigi Baltijos jūros regiono saugumo režimas ateityje galètų virsti tarsi dviem pagrindiniais ramsčiais besiremiančia ir visus regiono veikejus apimančia konstrukcija:

- Baltijos jūros regiono valstybės - NATO narès - Vokietija, Danija, Lenkija, Lietuva, Latvija ir Estija;

- Baltijos jūros regiono valstybès - NATO partnerès - Švedija, Suomija ir Rusija

Bet, žinoma, kol kas lieka neaišku, kaip veiks ir ar veiks iš viso tokia konstrukcija. Tai bus galima pamatyti, kaip po šių pasikeitimų klostysis Baltijos valstybių ir Rusijos santykiai, tačiau šiandien atrodo, kad visos prielaidos saugumui ir stabilumui užtikrinti nieko nepaliekant už borto ir neignoruojant yra kuo puikiausios. 